\title{
OPPORTUNITIES AND LIMITATIONS IN THE PROVISION OF SELF- HELP LEGAL RESOURCES TO CITIZENS IN NEED
}

\author{
Merran Lawler* \\ Jeff Giddings** \\ Michael Robertson ${ }^{* * *}$
}

This article considers the utility of resources designed to assist people undertaking their own legal work. Four in-depth case studies are used to explore the tensions inherent in providing coherent and user-oriented resources to legal self-helpers in environments where service providers attempt to convey complex legal information, knowledge and skills to people at the point of legal exigency. The needs of the consumer for basic process oriented and solutions focused resources do not always coincide with the objectives of providers to impart sufficient legal knowledge, information and skills to allow the consumer to work through those processes as an informed citizen.

Cet article porte sur l'utilité des ressources conçues pour aider les gens à effectuer eux-mêmes le travail juridique qu'ils requièrent. Quatre études de cas approfondies servent à examiner les tensions inhérentes à la distribution de ressources d'auto-assistance juridique cohérentes axées sur l'utilisateur dans des milieux où les fournisseurs de services cherchent à transmettre des connaissances, de l'information et des compétences juridiques complexes, selon les exigences de la loi. La nécessité pour le client d'obtenir des ressources axées sur les solutions et les procédures de base ne va pas toujours dans le sens de l'objectif des fournisseurs de services, qui consiste à lui transmettre des connaissances, de l'information et des compétences juridiques suffisantes pour qu'il puisse mener à bien ces procédures en tant que citoyen informé.

\section{INTRODUCTION}

This article reports on a specific range of findings from a three year qualitative research study exploring the landscape of self-help legal resources and practices within Australia. ${ }^{1}$ The full ambit of the study involved exploring the utility of self-

* Law School, Griffith University Gold Coast, Australia.

** Law School, Griffith University Brisbane, Australia.

*** University of Southern Queensland, Toowoomba, Australia.

1 The project was funded through an Australian Research Council [ARC] Discovery Grant. 
help legal resources across four specific types of legal matters. Its purpose was to gain a much clearer understanding of both the potential for and limits of self-help in the legal landscape. Rather than covering the field in terms of the entire project and all of our findings, our intention in this article is to focus on a series of observations and conclusions arising from our analysis of the project data as it relates to the interface and potential mismatch between the expressed needs and motivations of legal self-helpers and the expressed purposes and motivations of legal self-help resource providers.

In this article we seek to interrogate the question of whether, at a point of legal exigency, ${ }^{3}$ the needs of individual users for basic process oriented and solutions focused self-help resources (a common recurring need expressed by self-helpers throughout each of the four case studies we explored) conflict with and potentially undermine the importance providers attach to imparting sufficient legal knowledge, information and skills to allow the user to work through the required legal processes as an "informed citizen". Our research indicates that where the needs and motivations of the legal self-helper are at odds with the objectives of the resource provider, the utility of the self-help product, as measured from the perspective of the user, may be limited.

This article will explore whether this is a consequence of service providers approaching the development of self-help resources from an entirely law-centric perspective - a perspective in which legal knowledge and skills are considered more important and necessary for the self-helper than other non-legal skills. We will suggest that service providers may unwittingly and, despite their very best intentions, be acting as gatekeepers to the legal system, ensuring that only those self-helpers with sufficient legal knowledge and legal skill are permitted entry and are able to navigate that system successfully. Based on our research, a self-help resource designed to suit the provider's purposes may not only have limited utility for the user but may in fact frustrate or complicate the self-helper's access to the legal system, a notion we will expand upon throughout this article.

Some discussion of the broader research study is necessary in order to contextualise the content of this article. The next section of this article outlines the background to the project, providing details about our research methodology and the four case studies that constituted the project. In section III we analyse the case studies and draw out some common themes across each of the case studies relevant to the potential mismatch between the needs, desires and motivations of end-users and self-help resource providers before underlining the importance, as

2 Several of the individual case studies which form the basis of the research have been reported on elsewhere (see Merran Lawler, Jeff Giddings \& Michael Robertson, "Maybe a Solicitor Needs to Know That Sort of Thing but I Don't - User Perspectives on the Utility of Legal Self-Help Resources" in Alexy Buck, Pascoe Pleasence \& Nigel Balmer eds, Reaching Further: Innovation, Access and Quality in Legal Services (London: The Stationary Office, 2007) [User Perspectives] at 26 and Jeff Giddings, Merran Lawler \& Michael Robertson, "It's More Like Judge Judy - Selfhelp in a hybrid legal forum"(Paper delivered at the International Legal Aid Group Conference: Wellington, New Zealand, 2 April 2009), [unpublished] (on file with authors) [Hybrid Forums] By "legal exigency" we mean a point at which a person must take some form of legal action or make some type of legal decision in order to resolve a present or emerging legal problem. The point of legal exigency may involve a decision to commence some legal process, to defend a legal process brought by another or indeed, a decision to take no steps at all. What is significant about the point of legal exigency is that it requires the person to specifically turn their mind to what is occurring and is likely to occur in relation to their legal issue. 
we see it, of providers of self-help legal resources reaching a fuller understanding of the needs and motivations of legal self-helpers.

\section{BACKGROUND TO THE RESEARCH}

\section{A. The Need for Research into Legal Self-help}

Our research study was, in part, motivated by a lack of accessible knowledge about the legal landscape in Australia as it related to those who, either willingly or of necessity, assumed responsibility for some or all of the tasks associated with resolving their own legal issues. Our initial literature review of the field revealed that while there was an increasing body of research related to self-help legal activities, it tended to focus on:

- a perceived increase in the prevalence of legal self-help;

- exploration of the potential reasons for that perceived increase; and

- legal self-help confined to litigious matters only.

Notably, the available research tended to be silent about the particular experiences and perspectives of self-helpers themselves, instead focussing on explorations of the potential impacts of legal self-help on the smooth administration of justice. In addition, there had been only limited research which sought to consider questions about the suitability of self-help in different types of legal matters or in considering the capabilities of potential self-helpers to engage in the resolution of their own legal problems.

The phenomenon of legal self-representation in Australia has, in the last ten years, attracted increased attention, particularly in the context of traditionally litigious court and tribunal-based matters. ${ }^{4}$ Much of that attention has been motivated by concerns about the impact of unrepresented litigants on the courts and tribunals themselves rather than the impacts on the experiences and outcomes for self-helpers in legal forums or indeed, the impacts on the notion of "justice" itself. The challenges involved in exploring anecdotal evidence of growth in the number of unrepresented litigants and any potential link with shrinking legal aid

4 See e.g. Australian Law Reform Commission, Managing Justice: A Review of the Federal Justice

System (Canberra: Australian Law Reform Commission, 2000); Family Law Council, Litigants in Person: A Report to the Attorney-General (Canberra: Family Law Council, 2000); Rosemary Hunter, Jeff Giddings \& April Chrzanowski, Legal Aid and Self-Representation in the Family Court of Australia (Brisbane: Socio-Legal Research Centre, May 2003); Senate Legal and Constitutional References Committee, Legal Aid and Access to Justice: Final Report (Canberra: Commonwealth Parliament of Australia, June 2004) at ch 10 ; Federal Magistrates Court, An Evaluation of Services for Self-Represented Litigants in the Federal Magistrates Court (Melbourne: Federal Magistrates Court, October 2004); Australian Institute of Judicial Administration and the Federal Court of Australia, Forum on Self-Represented Litigants Report (Sydney: Australian Institute of Judicial Administration, September 2004); Cate Banks, Rosemary Hunter \& Jeff Giddings, Australian Innovations in Legal Aid Services: Balancing Costs and Client Needs (Brisbane: Socio-Legal Research Centre, 2006); Simon Smith, Maverick Litigants (Elwood, Victoria: Maverick Press, 2009); Australian Government, Attorney-General's Department, A Strategic Framework for Access to Justice in the Federal Civil Justice System (Canberra: Commonwealth Attorney-General's Department, September 2009) at ch 8; and Senate Legal and Constitutional References Committee, Legal Aid and Access to Justice - Final Report (Canberra: Commonwealth Parliament of Australia, December 2009) at ch 5. 
budgets $^{5}$ were compounded by the fact that until the mid 1990s few courts and tribunals maintained data on the number of litigants in person accessing those forums.

The trend towards greater reliance on self-help in the resolution of legal matters is not, however, confined to Australia but includes evidence of increasing reliance on legal self-help in the United Kingdom ${ }^{6}$ and in North America, ${ }^{7}$ a trend which has also been linked to decreasing legal aid budgets in those jurisdictions.

Our review of existing literature indicates that little research had been undertaken to examine the frequency with which people engage in legal self-help in tribunals and other forums beyond courts and in relation to non-litigious matters which are resolved without the need for recourse to the courts. Little is known about the extent to which people engage in legal self-help outside of litigious environments and the experiences of these particular users of the law and its processes. There are, for example, a range of administrative matters involving welfare and other entitlements as well as real estate conveyances, wills and probate matters, uncontested family law arrangements and other disputes resolved through both informal and court-mandated consent agreements, where people engage in forms of legal self-help in order to resolve the legal problem or matter at hand. We have limited understanding of the availability and effectiveness of the plethora of self-help materials designed to allow people to work through their own non-litigious legal issues. The need to develop such understandings is particularly significant where people are expected to advocate for themselves as part of compulsory alternative dispute resolution (ADR) processes. While the development of mandated ADR has been closely analysed, ${ }^{9}$ this analysis has not

5 John Dewar, Jeff Giddings \& Stephen Parker, The Impact of Legal Aid Changes on Criminal and

Family Law Practice in Queensland (Brisbane: Socio Legal Research Centre, 1998).

6 Richard Moorhead, "Access or Aggravation? Litigants in Person, McKenzie Friends and Lay

Representation" (2003) 22 CJQ 133; Richard Moorhead \& Mark Sefton, Litigants in Person: Unrepresented Litigants in First Instance Proceedings (London: Department of Constitutional Affairs, 2005); Hazel Genn, Paths to Justice (Oxford: Hart Publishing, 1999).

7 Jona Goldschmidt, "The Pro Se Litigant's Struggle for Access to Justice" (2002) 40 (1) Fam Ct

Rev 36; Lynn Mather, "Changing Patterns of Legal Representation in Divorce: From Lawyers to Pro Se" (2003) 30 JL \& Soc'y 137; Paula Hannaford-Agor \& Nicole Mott, "Research on SelfRepresented Litigation: Preliminary Results and Methodological Considerations" (2003) 24(2) Justice System Journal 163; Richard Zorza, "The Disconnect Between the Requirements of Judicial Neutrality and Those of the Appearance of Neutrality When Parties Appear Pro Se: Causes, Solutions, Recommendations and Implications" (2004) 17 (3) Geo J Legal Ethics 423.

$8 \quad$ Francis Regan, "Rolls Royce or Rundown 1970s Kingswood?" (1997) 22(5) Alternative Law

Journal 225; Francis Regan, Alan Paterson, Tamara Goriely and Don Fleming, eds, The Transformation of Legal Aid: Comparative and Historical Studies (Oxford: Oxford University Press, 1999); Mary Anne Noone, "The State of Australian Legal Aid" (2001) 29 Federal Law Review 37.

9 National Alternative Dispute Resolution Advisory Council, The Resolve to Resolve: Embracing ADR to Improve Access to Justice in the Federal Jurisdiction (Canberra: Attorney-General's Department, 2009) at ch 2; Laurence Boulle, Mediation: Principles, Process, Practice (Chatswood, New South Wales: LexisNexis, 2005) at 23-28; Paul Venus, "Court-Directed Compulsory Mediation - Attendance or Participation?" (2004) 15 Australasian Dispute Resolution Journal 29; Ulrich Boettger, "Efficiency Versus Party Empowerment - Against a Good-Faith Requirement in Mandatory Mediation" (2004) 23 The Review of Litigation 1; Nancy Welsh, "The Place of a Court-Connected Mediation in a Democratic Justice System" (2004) 5(2) Cardozo Journal of Conflict Resolution 117; Magdelena McIntosh, "A Step Forward - Mandatory Mediations"(2003) 14 Australasian Dispute Resolution Journal 280; Gary Smith, "Unwilling 
addressed the utility of self-help resources in facilitating constructive selfadvocacy.

Finally, until very recently, ${ }^{10}$ there has been little empirical, published research which attempts to consider whether certain types of legal matters lend themselves more readily to a self-help approach than others, or indeed whether certain population groups are better placed to engage in legal self-help than other groups.

\section{B. The Research Project}

Our research project was conducted over a three year period from 2005-2008. Its purposes have been two-fold:

- $\quad$ to gain a much clearer understanding of both the potential for and limits of effective self-help legal resources; and

- $\quad$ to explore the nature of existing self-help resources and their relationship to other forms of legal services and support. This latter concern includes whether specific or specialised forms of assistance may be needed in particular types of legal matters, or for particular population groups engaged in legal self-help.

In considering the development of the project we were keen to draw on the lived experiences of legal self-helpers to develop a framework for understanding both the potential for, and limits of people taking either sole or substantial responsibility for the resolution of their own legal problems or issues. In part, this was intended to address the gap we had observed in the then available published research into self-help legal activities which tended to focus on the impacts of selfhelp on the broader system of justice rather than on those actually undertaking legal self-help.

For the purposes of the project we used a working definition of "self-help legal resources" encompassing all those resources, support mechanisms, structures and services which are designed to assist people to work through their own legal problems either independently or substantially independently of formal and comprehensive legal assistance.

The research project explored four distinct case studies involving instances of self-help in a legal environment. ${ }^{11}$ In framing our research, our focus has been to engage with self-help legal environments by reference to three broad "factor collections" or variables and to examine the ways in which those variables interplay in different legal environments. Those variables relate to:

Actors: Why Voluntary Mediation Works, Why Mandatory Mediation Might Not” (1998) 36 Osgoode Hall LJ 847.

10 This has increasingly been addressed in the last five years, at least internationally. See e.g.

Balmer et al, Knowledge, Capability and the Experience of Rights Problems (London: Public Legal Education Network, 2010) in relation to public legal education in the United Kingdom and its impact upon people's capacity to engage in processes in order to resolve legal problems for themselves.

11 The case-study methodology is discussed further in the next section of this article. It has been utilised to distinguish each of the four legal areas of self-help resources explored in our research. Each of those studies constitutes a discrete area of focus, an individual instance of self-help (albeit involving interviews with multiple self-helpers within each instance). 
1. The context or environment in which a self-help legal task is undertaken. This is a broad variable which seeks to take account of systemic factors such as the attitudes towards self-helpers demonstrated by officials within the particular element of the legal system, the nature of the motivation of the provider of relevant self-help resources that may be available, the circumstances in which legal self-help is undertaken (e.g. a matter of choice or of necessity) and whether the legal task is purely administrative or likely to be highly emotive for the self-helper.

2. The complexity of the relevant law and legal process. This extends beyond a simple legal analysis of what legal skills and knowledge might need to be brought to bear by the selfhelper to include the range of non-legal skills and abilities (such as basic literacy and numeracy skills) through to the ability to make informed decisions that a self-helper may need to possess or is presumed to possess; and

3. The personal characteristics of the self-helper who is undertaking his own legal work (including socio-economic indicators as well as broader considerations such as the willingness or otherwise of the self-helper to engage in the process of self-help).

The research sought to consider the interplay of the quantity, quality and combination of those variables across case studies involving four distinct self-help legal resources. In doing so our intention has been to consider the ways in which the context in which self-help is undertaken, the complexity of the legal transaction involved and the personal characteristics of the self-helper may impact upon the utility of a self-help legal resource from the self-helper's own perspective. In turn, we suggest this may illuminate our understanding of whether there are some instances in which self-help legal resources are more appropriate than other instances.

\section{Methodology}

The focus of the research has been a qualitative one. An initial literature review (some of which we have cited above) identified that there were significant gaps in our understanding of the lived experiences of legal self-helpers navigating through unknown legal terrains. We therefore sought to focus our research at the interstices of that unknown terrain and the existing but limited body of research relating to legal self-help, specifically in examining the utility of self-help legal resources as measured by users themselves in both litigious and non-litigious contexts.

We did not, however, seek to conduct a mere user "satisfaction survey" or limited "program evaluation" of each of the four self-help resources which formed the basis of our study. Rather our intention was to collect meaningful data from a variety of sources - from the self-helpers themselves, from self-help resource providers and from other stakeholders within each legal context (for example, tribunal personnel) - and to allow that data to speak to and about the interplay of the variables of context, complexity and user characteristics identified above. We 
were keen to avoid prescribing a definition of "utility" by which each resource could be measured but rather sought to allow participants within each study to give voice to their own measures of what was or was not useful for them personally in terms of the self-help resources they accessed. In addition, our data collection included instances of self-helpers who had used resources other than or in addition to the four specific products which formed the basis of each case study. This allowed for some exploration of the ways in which self-helpers identified and used a broad range of resources and how that might speak to the relationships between existing self-help resources and other forms of legal services and support.

\section{The Case Study Method}

Our research involved four separate and diverse case studies relating to the development and use of self-help legal resources. Our adoption of the case study approach was informed by the recognition that case studies are instrumental in nature in that they provide opportunities to identify insights into common issues and to draw out broad generalisations. ${ }^{12}$ In addition, given that each case study is of interest in and of itself, they are also what Stake describes as intrinsic in nature.

The case study method allowed us to explore each context in detail by:

- examining the available self-help resources through a detailed process of textual analysis;

- documenting the experiences of those who had used the resource (as well as those who had not) through the use of semi-structured and narrative based interviews,

- collating information derived from standard demographic and socio-economic data sets of users; and

- documenting the insights of self-help resource providers and other important stakeholders, also through the use of semistructured interviews.

The triangulation made possible by these multiple data collection methods provided for stronger substantiation of the theories developed. ${ }^{14}$ The data collection and data analysis phases overlapped, enabling advantage to be taken of flexible data collection, a key feature of theory-building case research. ${ }^{15}$

Within-case analysis was undertaken through detailed write-ups of each selfhelp setting. This assisted in developing a close familiarity with each case study

12 Robert Stake, "Qualitative Case Studies" in Norman Denzin \& Yvonna Lincoln eds, The Sage

Handbook of Qualitative Research, $3^{\text {rd }}$ ed (California: Sage Publications Inc, 2005) 443 at 445. See also Catherine Marshall \& Gretchen Rossman, Designing Qualitative Research, $4^{\text {th }}$ ed (California: Sage Publications Inc, 2006) 55.

13 Stake, ibid. While we were interested in generalising and extrapolating from the case studies, we were also concerned to better understand each particular case.

14 Kathleen Eisenhardt, "Building Theories From Case Study Research" (1989) 14(4) Academy of Management Review 532 at 538.

$15 \quad$ Ibid at 539. 
and in accelerating the comparison across studies. ${ }^{16}$ The four case studies were then analysed with a view to identifying similarities and differences with all the case study data being analysed, using a table setting out the three key variables: context, complexity and user characteristics. Miles and Huberman have identified the use of tables as a method for managing qualitative data "without destroying the meaning of the data through intensive coding".

\section{Selection of case studies}

The four case studies which form the basis of our research involved:

1. Obtaining probate of a will (uncontested) in the Supreme Court of Victoria;

2. Pursuing a tenancy matter in the then Small Claims Tribunal of Queensland;

3. Commencing or defending a small contractual dispute in the consumer division of the then Small Claims Tribunal of Queensland; and

4. Conducting a dispute within the child protection system within Queensland.

In determining the case studies, we conducted an extended survey of known selfhelp resources in Australia drawing upon internet searches, liaison with statebased courts and tribunals, legal aid organisations and particularly the National Association of Community Legal Centres which maintains a database of known self-help legal resources produced throughout Australia.

Given the breadth of our research project, selection of the four case studies was based upon their potential to yield data relevant to the three variables previously outlined.

Table 1: Classification of case studies by variables

\begin{tabular}{|l|l|l|l|l|}
\hline Variable & $\begin{array}{l}\text { Case Study \#1 } \\
\text { Probate }\end{array}$ & $\begin{array}{l}\text { Case Study \# 2 } \\
\text { Tenancy }\end{array}$ & $\begin{array}{l}\text { Case Study \# 3 } \\
\text { Contractual } \\
\text { Dispute }\end{array}$ & $\begin{array}{l}\text { Case Study \# 4 } \\
\text { Child } \\
\text { protection }\end{array}$ \\
\hline Context & $\begin{array}{l}\text { Anticipates legal } \\
\text { representation; } \\
\text { tolerates self-help }\end{array}$ & $\begin{array}{l}\text { Mandates self- } \\
\text { help; prohibits } \\
\text { legal response } \\
\text { representation } \\
\text { except in } \\
\text { exceptional } \\
\text { circumstances }\end{array}$ & $\begin{array}{l}\text { Mandates self- } \\
\text { help and } \\
\text { prohibits legal } \\
\text { representation } \\
\text { except in } \\
\text { exceptional in } \\
\text { circumstances }\end{array}$ & $\begin{array}{l}\text { Anticipates and } \\
\text { encourages } \\
\text { legal } \\
\text { representation; } \\
\text { intolerant } \\
\text { self-help }\end{array}$ \\
\hline $\begin{array}{l}\text { Decision } \\
\text { engage in self- } \\
\text { help }\end{array}$ & $\begin{array}{l}\text { Self-help } \\
\text { voluntary } \\
\text { is }\end{array}$ & $\begin{array}{l}\text { Self-help } \\
\text { required } \\
\text { required }\end{array}$ & $\begin{array}{l}\text { Self-help } \\
\text { voluntary } \\
\text { often motivated } \\
\text { by having no } \\
\text { but } \\
\text { other choice. }\end{array}$ \\
\hline
\end{tabular}

Ibid at 540.

17 Matthew Miles \& Michael Huberman, Qualitative Data Analysis (1984), cited by Eisenhardt, supra note 14 at 534 . 


\begin{tabular}{|c|c|c|c|c|}
\hline Variable & $\begin{array}{l}\text { Case Study \#1 } \\
\text { Probate }\end{array}$ & $\begin{array}{l}\text { Case Study \# } 2 \\
\text { Tenancy }\end{array}$ & $\begin{array}{l}\text { Case Study \# } 3 \\
\text { Contractual } \\
\text { Dispute } \\
\end{array}$ & $\begin{array}{l}\text { Case Study \# } 4 \\
\text { Child } \\
\text { protection }\end{array}$ \\
\hline $\begin{array}{l}\text { Nature of self- } \\
\text { help resource } \\
\text { provider }\end{array}$ & $\begin{array}{l}\text { Private for profit } \\
\text { company }\end{array}$ & $\begin{array}{l}\text { Statutory } \\
\text { authority }\end{array}$ & $\begin{array}{l}\text { Statutory Legal } \\
\text { Aid body }\end{array}$ & $\begin{array}{l}\text { Community } \\
\text { based legal } \\
\text { service }\end{array}$ \\
\hline $\begin{array}{l}\text { Nature of legal } \\
\text { matter }\end{array}$ & Non-litigious & $\begin{array}{ll}\text { Potentially } & \\
\text { litigious } & \\
\text { depending } & \text { upon } \\
\text { response } & \text { from } \\
\text { other party } & \end{array}$ & Litigious & Litigious \\
\hline $\begin{array}{ll}\text { Availability of } \\
\text { Alternative } \\
\text { Dispute } \\
\text { Resolution } \\
\text { processes }\end{array}$ & Not applicable & $\begin{array}{l}\text { Compulsory pre- } \\
\text { action mediation } \\
\text { hearings }\end{array}$ & $\begin{array}{l}\text { Limited pre- } \\
\text { hearing } \\
\text { mediation } \\
\text { available but not } \\
\text { compulsory }\end{array}$ & Nil \\
\hline $\begin{array}{l}\text { Nature of legal } \\
\text { task/process }\end{array}$ & $\begin{array}{l}\text { Largely } \\
\text { administrative } \\
\text { with low level of } \\
\text { discretion on part } \\
\text { of ultimate } \\
\text { decision maker. } \\
\text { Importantly, } \\
\text { applicant can re- } \\
\text { submit if initially } \\
\text { unsuccessful }\end{array}$ & $\begin{array}{l}\text { Both } \\
\text { administrative } \\
\text { and legal in } \\
\text { nature. Low to } \\
\text { medium level of } \\
\text { discretion on the } \\
\text { part of ultimate } \\
\text { decision maker. } \\
\text { No right of } \\
\text { appeal. }\end{array}$ & $\begin{array}{l}\text { Both } \\
\text { administrative } \\
\text { and legal in } \\
\text { nature. Medium } \\
\text { to high level of } \\
\text { discretion on part } \\
\text { of ultimate } \\
\text { decision maker. } \\
\text { Limited right of } \\
\text { appeal on } \\
\text { question of law } \\
\text { only. }\end{array}$ & $\begin{array}{l}\text { Largely legal in } \\
\text { nature. High } \\
\text { levels of } \\
\text { discretion on } \\
\text { part of ultimate } \\
\text { decision maker. } \\
\text { Rights of appeal } \\
\text { dependent on } \\
\text { nature } \\
\text { original case. }\end{array}$ \\
\hline $\begin{array}{l}\text { Anticipated } \\
\text { emotional } \\
\text { attachment on } \\
\text { part of self- } \\
\text { helper to process } \\
\text { and outcome }\end{array}$ & $\begin{array}{l}\text { Low to medium } \\
\text { levels } \\
\text { emotional } \\
\text { attachment to } \\
\text { process. Medium } \\
\text { to high levels of } \\
\text { emotional } \\
\text { attachment to } \\
\text { outcome. }\end{array}$ & $\begin{array}{lr}\begin{array}{l}\text { Low to } \\
\text { levels }\end{array} & \text { high } \\
\text { emotional } & \\
\text { attachment } & \text { to } \\
\text { process. } & \\
\text { Medium to } & \text { high } \\
\text { levels } & \text { of } \\
\text { emotional } & \\
\text { attachment } & \text { to } \\
\text { outcome. } & \\
\end{array}$ & 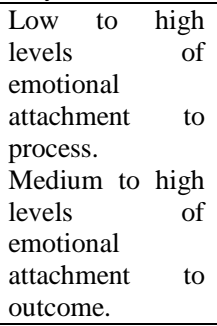 & $\begin{array}{l}\text { Medium to high } \\
\text { levels } \\
\text { emotional } \\
\text { attachment to } \\
\text { process. } \\
\text { High levels of } \\
\text { emotional } \\
\text { attachment to } \\
\text { outcome. }\end{array}$ \\
\hline \multicolumn{5}{|l|}{ Complexity } \\
\hline $\begin{array}{l}\text { Level of legal } \\
\text { knowledge } \\
\text { required }\end{array}$ & $\begin{array}{l}\text { Limited } \\
\text { requirement to } \\
\text { understand key } \\
\text { probate terms and } \\
\text { basic steps in } \\
\text { process }\end{array}$ & $\begin{array}{lr}\begin{array}{l}\text { Limited } \\
\text { requirement }\end{array} \\
\text { understand } \\
\text { rights key } \\
\text { obligations } & \text { and } \\
\text { tenant as } \\
\text { landlord } \\
\begin{array}{l}\text { basic ar } \\
\text { process }\end{array}\end{array}$ & $\begin{array}{l}\text { Requirement to } \\
\text { understand basic } \\
\text { contract law } \\
\text { including parties, } \\
\text { elements, } \\
\text { remedies and } \\
\text { some advanced } \\
\text { steps in process } \\
\text { (e.g. relevance of } \\
\text { evidence) }\end{array}$ & $\begin{array}{l}\text { Highly complex } \\
\text { legal field with } \\
\text { relationship to } \\
\text { other areas of } \\
\text { law (e.g. } \\
\text { criminal, family } \\
\text { law, } \\
\text { administrative } \\
\text { law) and strong } \\
\text { knowledge of } \\
\text { process (e.g. } \\
\text { affidavit } \\
\text { preparation, } \\
\text { relevance of } \\
\text { evidence) }\end{array}$ \\
\hline $\begin{array}{lr}\text { Nature } & \text { of } \\
\text { required } & \text { non- } \\
\text { legal skills } & \end{array}$ & $\begin{array}{l}\text { Literacy and } \\
\text { numeracy skills } \\
\text { sufficient to read } \\
\text { and complete pre- } \\
\text { printed forms. } \\
\text { Limited skills in } \\
\text { making informed }\end{array}$ & $\begin{array}{l}\text { Literacy and } \\
\text { numeracy skills } \\
\text { sufficient to read } \\
\text { and complete } \\
\text { pre-printed } \\
\text { forms. } \\
\text { Capacity to }\end{array}$ & $\begin{array}{l}\text { Literacy and } \\
\text { numeracy skills } \\
\text { sufficient to read } \\
\text { and complete } \\
\text { pre-printed } \\
\text { forms. } \\
\text { Capacity to }\end{array}$ & $\begin{array}{lr}\text { Literacy } & \text { skills } \\
\text { sufficient } & \text { to } \\
\text { read } & \text { and } \\
\text { complete } & \text { pre- } \\
\text { printed forms } \\
\text { and structure } \\
\text { and present }\end{array}$ \\
\hline
\end{tabular}




\begin{tabular}{|c|c|c|c|c|}
\hline Variable & $\begin{array}{l}\text { Case Study \#1 } \\
\text { Probate }\end{array}$ & $\begin{array}{l}\text { Case Study \# } 2 \\
\text { Tenancy }\end{array}$ & $\begin{array}{l}\text { Case Study \# } 3 \\
\text { Contractual } \\
\text { Dispute }\end{array}$ & $\begin{array}{l}\text { Case Study \# } 4 \\
\text { Child } \\
\text { protection }\end{array}$ \\
\hline & $\begin{array}{l}\text { personal } \\
\text { decisions. }\end{array}$ & $\begin{array}{l}\text { verbally present } \\
\text { relevant } \\
\text { information in } \\
\text { coherent manner. } \\
\text { Reasonable } \\
\text { decision making } \\
\text { skills necessary } \\
\text { to consider } \\
\text { proposals for } \\
\text { settlement and } \\
\text { available } \\
\text { alternative } \\
\text { options within } \\
\text { limited range of } \\
\text { potential } \\
\text { outcomes. }\end{array}$ & $\begin{array}{l}\text { verbally present } \\
\text { relevant } \\
\text { information in } \\
\text { coherent manner. } \\
\text { Solid personal } \\
\text { decision making } \\
\text { skills necessary } \\
\text { to consider } \\
\text { proposals for } \\
\text { settlement and } \\
\text { available } \\
\text { alternative } \\
\text { options within } \\
\text { wide range of } \\
\text { potential } \\
\text { outcomes. }\end{array}$ & $\begin{array}{l}\text { relevant } \\
\text { information in } \\
\text { coherent } \\
\text { manner } \\
\text { (including } \\
\text { affidavit } \\
\text { material). } \\
\text { Capacity to } \\
\text { verbally present } \\
\text { relevant } \\
\text { information in a } \\
\text { coherent } \\
\text { manner. High } \\
\text { level personal } \\
\text { decision making } \\
\text { skills necessary } \\
\text { to consider } \\
\text { proposals for } \\
\text { settlement and } \\
\text { available } \\
\text { alternative } \\
\text { options within } \\
\text { wide range of } \\
\text { potential } \\
\text { outcomes. }\end{array}$ \\
\hline \multicolumn{5}{|l|}{ Characteristics } \\
\hline $\begin{array}{l}\text { Anticipated } \\
\text { socio-economic } \\
\text { backgrounds of } \\
\text { potential self- } \\
\text { helpers }\end{array}$ & Medium & Low to high & Low to high & Low \\
\hline
\end{tabular}

Each case study involved an instance of legal self-help but spoke to different aspects within each variable and illuminated the different contexts for the use of self-help, from highly litigious matters involving complex procedures and substantive law (for example child protection) to arenas involving legal processes that are non-litigious and more administrative in nature (such as probate applications). Similarly, the case studies explored different environments in which legal self-help is not only encouraged but explicitly required (those involving the Small Claims Tribunal in Queensland) as well as environments in which few concessions have been made to accommodate even the potentiality, let alone the actuality of self-helpers (again, notably matters involving child protection law). We were particularly concerned to consider the ways in which these case studies complement each other and might then suggest common themes about the experiences of self-helpers navigating the legal landscape represented in each study, notwithstanding that those landscapes differ significantly from each other.

In addition, our choice of case studies was dependent upon a range of practical factors. It was necessary for example to obtain the permission of the providers of each self-help resource, in part to ensure that we would have access to useful information held by the providers about the processes of developing and distributing the resource as well as any data about the user base for each resource. We also needed to identify resources which had a reasonable distribution and had been in existence for a period of time sufficient to yield up pools of potential 
participants who had used the resource in working through their legal matter. Finally, given our intention to obtain data from stakeholders within each system, (such as court personnel) about their perspectives on self-helpers who had (and had not) used the resource, it was necessary for us to identify self-help resources which would yield up willing participants from clearly definable key stakeholder groups. For these reasons, a range of potential self-help resources which might form the basis of our case studies were considered but discarded.

\section{Data Collection}

As previously mentioned, the data collected throughout the project fell into four distinct categories:

1. Textual analysis of each self-help resource which formed the basis of each case study;

2. Semi-structured interviews with key personnel working with or for the provider of the resource;

3. Semi-structured narrative interviews with self-helpers within the particular field, some of whom had used the resource and others who had not used the resource; and

4. Where possible, semi-structured interviews with relevant stakeholders within each of the legal systems impacted by self-helpers.

The textual analysis served multiple purposes. ${ }^{18}$ It provided an opportunity to familiarise ourselves with the self-help resource in detail and to develop a nuanced understanding of the particular legal process or matter under consideration - a process which often required reading outside the text itself by accessing relevant legislation, court rules and the like. Secondly, it enabled both close and critical reading in order to understand the particular areas of focus of, as well as the assumptions made by, the provider, revealing as much by what was omitted as by what was included. It also allowed us to consider the implicit and explicit messages the provider conveyed (either intentionally or otherwise) to the reader. In addition, the textual analysis allowed us to identify the points at which a selfhelper might be referred to (either implicitly or explicitly) other forms of assistance in resolving their matter. Finally, it provided an opportunity to consider the intended audience gauging, by the language used, the provider's expectations in relation to skill levels and capabilities of the likely user of the resource.

Semi-structured interviews with the providers of each of the four self-help resources were conducted prior to interviewing self-helpers. Providers generally nominated one or two key personnel responsible for the development and/or maintenance of the resource to be interviewed. A member of the research team conducted each interview which was recorded and then transcribed. The purpose of each interview was to explore the provider's reasons for developing the resource and the processes engaged in by the provider in the development, distribution and revision stages. Additionally, information was sought from those providers about their knowledge of other similar (sometimes competing and

18 Klaus Krippendorf, Content Analysis: An Introduction to Its Methodology, 2nd ed (Thousand

Oaks, CA: Sage Publications, 2004). 
sometimes complementary) resources and their perspectives on self-helpers working through the particular legal matter (both those who did or did not use the resource) as well as the ways in which the other work of the provider (for example, the provision of discrete instances of legal advice) might inform their development of self-help resources. Where possible, we also sought to obtain statistical data about use of the resource, although it is significant to note that three providers had no mechanisms for measuring usage and the other had only a vague idea based upon the number of hard copies printed.

The single largest data collection process involved semi-structured narrative interviews with self-helpers who had or were working through the relevant legal processes anticipated by the self-help resource in each case study. Given that the focus of our study was a qualitative one and our aim was therefore to identify information-rich potential participants, ${ }^{19}$ we sought to utilise non-probability convenience sampling, initially through a form of "snowballing" by working with the providers of each of the four self-help resources and other significant stakeholders (e.g. court and tribunal personnel, community legal centres) to identify pools of potential research participants.

While acknowledging the limitations ${ }^{20}$ of that technique we were mindful of the "hidden" or at least difficult to reach nature of the populations that might meaningfully contribute to each case study within the research. ${ }^{21}$ This was evident in the difficulty of ascertaining the boundaries of the sampling frame. While conceivably each case study involved "people who had experienced $X$ legal matter and had undertaken some or all of the tasks through legal self-help", no readily available data was available (for example from courts) to allow for identification of those who fell within the target populations. Moreover, given the confidential nature which generally attaches to legal processes and the reluctance of people to publically acknowledge their legal problems, we considered that other forms of sampling were unlikely to either reveal the extent of the relevant populations or yield reliable and relevant data.

Generic invitations were extended to potential participants identified through the referral processes we engaged in with self-help service providers and other stakeholders. In two of the case studies, invitations were sent by mail and in the other two posters were displayed in court and tribunal registries and in agencies which provided limited assistance services to self-helpers in the legal system generally.

The referral method of identifying potential research participants was supplemented by a form of direct recruitment whereby a member of the research team attended at court and tribunal registries in order to canvass people about their willingness to participate in the research.

Those who did participate tended to self-identify as coming within a particular case study, usually, but not always, because they had actually used the self-help resource which was part of the focus of each case study. Some participants had

19 Michael Patton, Qualitative evaluation and research methods (Newbury Park, CA: Sage Publications, 2002).

20 Douglas Heckathorn, "Respondent-Driven Sampling: A New Approach to the Study of Hidden Populations" (1997) 44(2) Social Problems 174.

2

Ibid. 
used alternate resources while some had not accessed any formal resources that they were able to identify as having aided them in their self-help journey.

The number of participants in each case study varied between 16 and 26. With the exception of one case study (relating to probate applications), recruitment of potential participants was more problematic than first anticipated. People who had already resolved their legal problems through self-help processes were arguably reluctant to revisit experiences they viewed as either painful or annoying. Others approached by a member of the research team generally indicated that they could not afford the time to participate in the research, indeed many of them viewed the particular legal process they were involved in as having already consumed more than enough of their valuable time.

\section{Table 2: Case study recruitment method}

\begin{tabular}{|c|c|c|c|c|}
\hline $\begin{array}{ll}\text { Method } & \text { of } \\
\text { Recruitment }\end{array}$ & $\begin{array}{l}\text { Case Study \#1 } \\
\text { Probate } \\
N=21\end{array}$ & $\begin{array}{l}\text { Case Study \# } 2 \\
\text { Tenancy } \\
N=26\end{array}$ & $\begin{array}{l}\text { Case Study \# } 3 \\
\text { Contractual } \\
\text { Dispute } \\
N=19 \\
\end{array}$ & $\begin{array}{l}\text { Case Study \# } 4 \\
\text { Child } \\
\text { protection } \\
N=16\end{array}$ \\
\hline $\begin{array}{l}\text { Responded to } \\
\text { mail invitations } \\
{[\mathrm{n}=\text { invitations }} \\
\text { sent }]\end{array}$ & $\begin{array}{l}15 \\
{[70]}\end{array}$ & $\begin{array}{l}0 \\
{[0]}\end{array}$ & $\begin{array}{l}0 \\
{[0]}\end{array}$ & $\begin{array}{l}5 \\
{[22]}\end{array}$ \\
\hline $\begin{array}{lr}\text { Responded } & \text { to } \\
\text { posters and other } \\
\text { forms } \\
\text { advertising }\end{array}$ & 0 & 14 & 9 & 2 \\
\hline $\begin{array}{ll}\text { Referred } & \text { directly } \\
\text { by } & \text { service } \\
\text { provider } & \\
\end{array}$ & 3 & 1 & 2 & 0 \\
\hline $\begin{array}{l}\text { Referred directly } \\
\text { by other } \\
\text { stakeholder }\end{array}$ & 1 & 3 & 2 & 5 \\
\hline $\begin{array}{l}\text { Responded to } \\
\text { canvassing by } \\
\text { researchers at } \\
\text { court/tribunal } \\
\text { [n = people } \\
\text { canvassed] }\end{array}$ & $\begin{array}{l}2 \\
{[5]}\end{array}$ & $\begin{array}{l}8 \\
{[37]}\end{array}$ & $\begin{array}{l}6 \\
{[43]}\end{array}$ & $\begin{array}{l}4 \\
{[6]}\end{array}$ \\
\hline
\end{tabular}

Interviews were generally conducted in the homes or work places of those who volunteered to participate in the research. In some instances, due to either distance or time constraints, interviews were conducted by telephone. Most interviews were audio recorded and these were eventually transcribed so that the research team could analyse the content more effectively.

The interview questions asked of self-helper participants were generally the same across all four case studies with minor variations to take into account the self-help resources specific to the case study as well as the variations in legal processes. Questions were designed to elicit responses in four broad categories:

22 Typical responses included "I was dragged into this whole mess. I don't want to be here and I don't want to waste your time telling you why I don't want to be here" and "Will talking to you help me? No! Not unless you're going to go in through those doors and be my lawyer so really, what good will it do me?" 
1. Those directed towards the participant being able to provide a narrative account of the particular circumstances of their legal problem or issue;

2. Those relating to the steps the participant undertook in gaining information and support to work through the legal problem as a self-helper;

3. Those designed to explore the participant's understanding of the legal processes and individual tasks they had engaged in; and

4. Questions which allowed the participant to reflect upon their own measures as to the effectiveness and utility of any self-help materials they had used throughout the legal process.

Participants also completed a standard questionnaire which provided useful demographic data relating to age, education levels and other relevant socioeconomic indicators.

In addition to the initial interviews conducted with the providers of relevant self-help resources, we also interviewed stakeholders who we had identified would be in a position to provide useful insights into the experiences of self-helpers within the legal system. Those stakeholders included staff working in the relevant court or tribunal as well as those working for other legal service providers. In this regard, staff of community legal centres provided a wealth of useful information about their experiences in working with self-helpers within the fields covered by the case studies given that so much of the work of community legal centres in Australia necessarily involves limited legal assistance (initial advice, checking of client-prepared documents and step-by-step guidance through legal processes).

In the next section we will outline in some detail each of the four case studies which comprised the research project. That exploration will provide context for the remainder of this article in terms of drawing out the common themes across those case studies as they relate to the potential mismatch between user and provider motivations and intentions.

\section{The Case Studies}

\section{Case Study \#1: Probate in the Supreme Court of Victoria}

This case study explored the experiences of 21 people who had made or were in the process of making application for orders for probate of a will in the Supreme Court of Victoria following the death of a relative or friend. Although the process of applying for probate is court-based, it is usually non-litigious inasmuch as orders are granted unopposed (known as common form probate) subject to the applicant following a defined process and no other party coming forward to dispute the grant of probate. In such instances, the process requires the applicant to attend at the Court registry ${ }^{23}$ in order to conduct searches of registry records, to advertise the intention to apply for probate in a daily newspaper and then a further

23 Note that the process changed in 2009 to allow for searches to be conducted online. In addition, the requirement for advertising in a daily newspaper has been removed and replaced with an online advertising process through the Supreme Court of Victoria website. 
attendance at court to file the application. There is however no court hearing. Applications are granted in the absence of the applicant and a copy of the Probate Order is sent by mail to the applicant. Importantly, an unsuccessful application does not preclude a subsequent application resulting in a grant of probate.

The Supreme Court of Victoria receives more than 14,000 applications for probate annually of which less than 100 are considered contentious. ${ }^{24}$ The Court does not however maintain data on the number of applications lodged by applicants in person rather than by legal practitioners (a factor which contributed to the problem of identifying the sample frame for our research). In New South Wales, a jurisdiction which operates a very similar probate application scheme to that in Victoria (and in which there are equivalent self-help resources to assist people to make their own application for probate) approximately $2.5 \%$ of applications filed are made by applicants personally. ${ }^{25}$ Assuming that the same would hold true in Victoria, this would suggest that some 300-400 applications annually are made by self-helpers undertaking their own legal work. Notwithstanding this, applications by legal practitioners on behalf of applicants remain the most significant source of all probate applications.

All 21 participants in the research case study had utilised a printed 78 page self-help kit How to Apply for Probate in Victoria with no Lawyer ${ }^{26}$ (hereafter The Probate Kit) produced by a private company, Law Kits of Victoria (LKV), to assist them in working through the application process. The Probate Kit is sold on a commercial basis for AUD\$77.00 ${ }^{27}$ (roughly equivalent to CAD\$77.00 or USD \$74.00) and is intended as a stand-alone product, although it can also be supplemented by additional support services provided by LKV (telephone support, document preparation and document checking) for the payment of a small fee (A\$15.00). Only three of the participants purchased the additional support although seven participants in total reported that they had in fact obtained further support and guidance from the staff of LKV via telephone.

Our initial literature review of the probate field indicated that in addition to free and accessible internet-based information about the processes of applying for probate in Victoria (including basic information provided on the Supreme Court of Victoria website) there were at least eight other kits and Guides available in the jurisdiction to assist people who wished to make their own application for probate.

The Probate Kit was developed by and is regularly updated by non-lawyers. Director of LKV, Dale Sedgeman reported that while a lawyer checks the accuracy of legal information in the kit, its content and language is designed by people without formal legal qualifications. ${ }^{28}$ It is reviewed and updated at least once each year and user feedback is actively sought as part of this process. Sedgeman indicated that The Probate Kit is intended to be a comprehensive self-help Guide

24 Supreme Court of Victoria, 2006-2007 Annual Report (Melbourne: Supreme Court of Victoria, 2007).

25 Supreme Court of New South Wales, Annual Review 2002 (Sydney: Supreme Court of NSW, 2003) at 34

26 Legal Kits Property Ltd, Legal Kits of Victoria How to Apply for Probate in Victoria with no Lawyer (Melbourne: Legal Kits of Victoria, 2006).

27 At the time of writing the purchase price had increased to AUD\$88.00.

28 Transcript of Interview with Dale Sedgeman on file with the authors. (23 October 2007) [Sedgeman Transcript] 
which people possessing average literacy and numerical skills should be able to work through to obtain the desired result of obtaining probate.

Twenty of the research participants successfully obtained a grant of probate in reliance upon the Probate Kit (and, in seven instances, with the additional services offered by LKV). In one further instance the participant initially utilised the kit but engaged a lawyer when it became apparent that the application was likely to be contested on the basis of a dispute about the validity of the will.

\section{Case Study \# 2: Tenancy disputes in Queensland}

Our second case involved 26 participants who were either applicants (18) or respondents (8) in at least one residential tenancy dispute in Queensland. Those matters included a range of disputes which were settled without the need to initiate formal legal action (17), ${ }^{29}$ as well as nine disputes which proceeded to at least the stage of filing an application (matters which could not be settled by compulsory pre-application alternative dispute resolution processes) with the Small Claims Tribunal, the body then responsible for the adjudication of residential tenancy disputes. ${ }^{30}$

Notwithstanding changes to the adjudicatory body dealing with tenancy disputes in Queensland which post-dated our case study, the legal processes associated with tenancy disputes in this jurisdiction, both then and now, not only encourage but expect individuals to engage in some level of self-help in the resolution of their legal difficulties. While people are free to consult and engage legal practitioners to provide advice and guidance about their tenancy problem, both the alternative dispute resolution mechanisms and the formal tribunal-based processes generally exclude legal practitioners from participating in conferences and hearings. We have explored elsewhere ${ }^{31}$ the increasing reliance upon tribunal type forums which compel those with legal problems to engage in self-help processes in order to resolve their legal problems.

The Small Claims Tribunal, prior to its replacement by the Queensland Civil and Administrative Tribunal routinely dealt with more than 15,000 cases annually. ${ }^{32}$ While publically available sources do not report the number of those claims which related solely to tenancy matters, extrapolation of data from the Queensland Magistrates Courts Annual Report for the period 2007-2008 $8^{33}$ relating to small claims matters filed in the Brisbane registry indicates that about $89 \%$ of all filed small claims related to tenancy disputes.

29 Notably, through compulsory pre-court action processes involving alternative dispute resolution mechanisms provided by the Residential Tenancies Authority, the body responsible for the administration of tenancies arrangements in Queensland.

[QCAT] on 1 December 2009. QCAT amalgamated the work of 23 separate jurisdictions which were previously vested in the Small Claims Tribunal, Magistrates Courts and specialist tribunals. The new body has a specific jurisdiction in relation to residential tenancy disputes and follows much the same process as that previously applicable in the SCT jurisdiction. Giddings et al (Hybrid Forums), supra note 2.

32 Magistrates Court of Queensland, Annual Report 2007-2008 (Brisbane: Magistrates Court of Queensland, October 2008) at 68.

33 Ibid at 70.

34 Comparable data is not available from QCAT since it took over responsibility for the adjudication of tenancy disputes in December 2009. Data from the Queensland Civil and Administrative 
The case study included examination of a 27 page guide, Handling Tenancy Disputes in the Small Claims Tribunal: A guide for all parties involved in renting in Queensland ${ }^{35}$ [Tenancy Guide] which was developed and distributed by the Residential Tenancies Authority [RTA], a statutory government operated body. Since the inception of the Queensland Civil and Administrative Tribunal the Tenancy Guide has been withdrawn by the RTA and replaced with a single page fact sheet accessible on the RTA website. ${ }^{36}$

The Tenancy Guide was freely available and provided as a matter of course to anyone who raised with the RTA a potential issue in relation to their regulated tenancy agreement. Because the process for pursuing a tenancy dispute necessarily involved an aggrieved person making initial contact with the RTA, that body was able to consistently refer people to the Guide either by posting it out to them or by referring them to an electronic copy of it on the RTA website. It is notable that of the 26 participants, 22 of them were aware of the existence of the Tenancy Guide (although only 16 participants reported using the Tenancy Guide as their primary self-help resource). Significantly, the Tenancy Guide was supplemented by the "pre-dispute" booklet ${ }^{37}$ which had to be provided to intending tenants by all landlords (or their agents) at the time a residential tenancy agreement was signed. The booklet outlined the rights and responsibilities of parties to a tenancy agreement. All study participants were aware of the existence of the pre-dispute booklet.

The Tenancy Guide was developed and updated by staff of the RTA working in the Policy and Education Services section. While it was checked by RTA lawyers for accuracy, the content and language were largely determined by nonlegally qualified staff who had expertise in community education and publications. ${ }^{38}$ The Guide was intended as a stand-alone product and no formal legal advice program was offered by the RTA, although process-oriented general guidance was available from RTA staff as well as personnel at the Small Claims Tribunal. Those who required additional legal advice (as opposed to basic process information) would routinely be referred to community legal centres and various tenants' advice and advocacy services. The provider indicated that the Guide was intended as a reasonably comprehensive self-help product developed to assist people to work through the process of a tenancy dispute with relative autonomy. ${ }^{39}$

Tribunal, Annual Report 2009-2010 (Brisbane: QCAT, 2010) at 16 indicates that a total of 12,619 tenancy matters were dealt with by QCAT in that year which represents approximately $60 \%$ of all claims filed in the minor civil disputes jurisdiction of the Tribunal, although it is noted that that jurisdiction is significantly more expansive than the jurisdiction of the former Small Claims Tribunal.

35 Residential Tenancies Authority, Handling Tenancy Disputes in the Small Claims Tribunal (Brisbane: Residential Tenancies Authority, 2009).

36 Queensland Government, Queensland Consumer and Administrative Tribunal, online: Residential Tenancies Authority <http://www.rta.qld.gov.au/Dispute-Assistance/Resolving-adispute/QCAT.aspx>.

37 Formerly known as "Know Your Rights" and now known as "Renting a House or Unit in Queensland Form 17a" (Brisbane: Residential Tenancies Authority, 2010).

38 Transcript of Interview with RTA General Manager, David Breen (on file with authors).

39 The Residential Tenancies Authority emphasises 'self-resolution', encouraging parties to manage and resolve their own disputes. See Queensland Government, Making a positive difference in Queensland, online: Residential Tenancies Authority, <http://www.rta.qld.gov.au/selfresolution.cfm>. 
The study involved interviews with 26 people who had undertaken legal selfhelp processes in relation to a tenancy problem. While most of those were tenants, the study included four landlords. Eighteen of the participants were applicants in the process, having commenced tenancy claims across a broad spectrum of matters, notably relating to rental arrears, challenges to proposed rental increases and claims for emergency repairs to premises (or reimbursement of expenses associated with undertaking those repairs). The remaining eight participants were respondents to claims commenced by the other party and seven of these were tenants seeking to avoid eviction for unpaid rental arrears.

Twenty-two of the participants had seen or had been referred to the Guide and, of those, 16 had utilised the Guide in working through the resolution of their legal problem. Those who had not utilised the Guide either had previous experience with the process of dealing with a tenancy dispute (two), had obtained guidance from a community legal centre or tenancy advice service (three) or obtained verbal information and guidance from the RTA and Small Claims Tribunal to work through the process (four). One applicant had obtained assistance from a variety of sources (attending an advice session at a community legal centre, sourcing materials available on the internet and obtaining information from the Small Claims Tribunal). Twenty-three of the participants had finalised their tenancy problem at the time they participated in the interview while three were still involved in the legal process.

\section{(a) Consumer (small contractual) disputes in Queensland}

This case study considered the use of self-help in the resolution of 19 small consumer disputes relating to contracts for goods and services in Queensland. Each of the claims involved monetary amounts of less than $\$ 7,500$ between two parties who fitted neatly within the requirements of being either a "consumer" or a "trader". At the time the case study was conducted, these disputes fell within the jurisdiction of the Small Claims Tribunal ${ }^{40}$ and, as in tenancy matters, the Tribunal processes provided very limited scope for the engagement of legal practitioners by parties involved in small consumer disputes.

The study included examination of a 36 page self-help Guide prepared by Legal Aid Queensland [LAQ], the Small Claims Tribunal: A Consumer Guide (hereinafter the "Consumer Guide"). While the publication was provided free of charge to potential SCT applicants (either through the LAQ website or through a distribution arrangement with the SCT itself), it is notable that of the 19 participants involved in the case study, only nine had seen the Guide and only five had utilised it in working their way through the legal process. By virtue of an arrangement between LAQ and the SCT, the Consumer Guide was normally distributed by the SCT registry to potential claimants but, at the time of the case study that distribution process was not available (and had not occurred for some six weeks) because the Guide was out of print.

Self-helpers who undertook the process without reference to the Consumer Guide tended to rely upon a combination of sources of assistance and information, notably from the SCT itself but also from private solicitors, community legal centres and the Queensland Office of Fair Trading. No information was available

40 Such claims now form part of the jurisdiction of the Queensland Civil and Administrative Tribunal. See supra note 30. 
from LAQ as to the number of copies of the Consumer Guide distributed to potential self-helpers on an annual basis.

It is evident from our analysis of the Consumer Guide together with our interviews with those responsible for its development that the publication was intended as a stand-alone, if limited self-help resource rather than as part of a suite of complementary services offered by the same provider. In this respect users were referred (by the words in the Consumer Guide itself) to legal practitioners, either privately retained or through Legal Aid Queensland and community legal centres. The self-help resource actively encouraged users to seek legal advice prior to commencing a claim in the SCT and also at various stages throughout the life of the claim. The text of the Consumer Guide made clear that it was intended as a source of "general information" only and was not intended as either a substitution for individualised legal assistance nor as a comprehensive "do-ityourself" product.

Legally qualified LAQ staff were responsible for developing the content of the Consumer Guide. It underwent significant revision in 2007 in order to incorporate LAQ's new direction towards a plain language approach for all of its publications but remained largely a production undertaken by LAQ lawyers.

Since the inception of the Queensland Consumer and Administrative Tribunal [QCAT] in December 2009, LAQ has withdrawn the Consumer Guide from publication. Very basic information about potential small consumer claims is now provided on the QCAT website. ${ }^{41}$

\section{(b) Child protection in Queensland}

The final case study focused upon the role of self-help legal resources for 16 people involved in the child protection system in Queensland. That system relates to a broad range of legal proceedings and processes, usually triggered by state intervention (through the Department of Child Safety) in the arrangements for the care of children by their parents and/or guardians in circumstances where allegations of neglect and/or abuse have been raised.

In 2007-2008 more than 6,500 applications were made for child protection orders to the Children's Court (a jurisdiction exercised by the Magistrates Court of Queensland) by the Department of Child Safety, ${ }^{42}$ the statutory body responsible for the protection of children in the state and more than 7,000 children were living away from home following interventions by the Department of Child Safety. ${ }^{43}$

There are multiple points at which people might find themselves adrift in the child protection system - principally when a child is removed from their care on an interim court-based protection order but also in relation to involvement in decisions made by officers of the Department of Child Safety (such as decisions to reduce parental contact with a child in state care) as well as when appealing such Departmental decisions.

For the purposes of our study we sought to focus on people who were engaged in the child protection system as a result of disputes with the decision making

41 See e.g. Queensland Government, Queensland Consumer and Administrative Tribunal, online:

Queensland Consumer and Administrative Tribunal <http://www.qcat.qld.gov.au/ >.

42 Department of Child Safety, Annual Report 2007-2008, online: Department of Child Safety

<http://www.communities.qld.gov.au/resources/childsafety/about-documents/ performancereport-2007-2008.pdf> at 39 .

$43 \quad$ Ibid at 6 
authority of the Department and subsequent appeals from those decisions to the then Children's Services Tribunal (the jurisdiction of which has now been subsumed into the Queensland Civil and Administrative Tribunal). Our rationale for doing so was that those situations tended to more frequently involve instances in which people dealing with the Department were ineligible for legal aid services and otherwise unable to fund their own costs of obtaining independent legal advice. LAQ funding priorities in relation to child protection matters (which fall within its civil aid budget) make some provision for funding of substantive matters before the Children's Court (for example, where a parent is seeking to challenge the making of an order placing a child in care) but do not provide for funding of matters which challenge Departmental decisions once a child protection order has been made. ${ }^{44}$

The study included examination of two publications by the South West Brisbane Community Legal Service (SWBCLS) - the Information Kit on Child Protection For Parents (2007) which is 27 pages in length (the Parents Kit) and the Information Kit on Child Protection for Kinship Carers (2007) which is 28 pages long (the Kinship Kit). While the Parents Kit is intended for use by those legally recognised as parents of children who are the subject of care and protection applications and orders, the Kinship Kit is intended for use by those who are considered to have a "significant relationship" (usually familial) with relevant subject children. Both kits are intended to be accessed, according to the resource provider as "general information" about "rights and responsibilities" rather than as a step-by-step Guide although both do provide some level of detail about the steps to be taken in relation to disputing Departmental decisions and also about review processes before the then Children's Services Tribunal. Both kits are accessible on line and in hard copy from the service provider.

We interviewed 16 participants who had engaged in self-help within the child protection system. Of those, nine had accessed the kit pertaining to kinship carers while two had accessed both kits. Of those, ten had accessed the kits as a result of obtaining at least initial legal advice and assistance from the service provider. Only one had located the kit for themselves through an internet search. Five participants had not been aware of the existence of either kit and had not sought legal assistance from the service provider. Instead, those participants had instead relied upon guidance from a range of support mechanisms including the then Children's Services Tribunal, Departmental officers and other legal aid and community legal service agencies.

Both kits were produced by legally qualified staff of the SWBCLS who determined both content and language. Notably, the provider was motivated to develop the kits because nothing else existed for parents and carers to help them through the maze of processes and legal complexities associated with child protection proceedings. Certainly, our own search for materials to assist legal selfhelpers revealed no other accessible information in this emotionally-fraught and legally complex area.

\footnotetext{
44 Legal Aid Queensland, Legal Aid Queensland Grants Handbook - chapter on civil law accessible, online: Legal Aid Queensland <https://elo.legalaid.qld.gov.au/grants handbook/default.asp>.

45 Child Protection Act, QLD 1999, s 5(2)(f)(iii).
} 


\section{ANALYSIS OF THE CASE STUDY DATA}

\section{A. Characterising the case studies}

For the purposes of data analysis, we have characterised each case study dependent upon the type of provider involved in developing and distributing the resource and the background circumstances relevant to the user undertaking selfhelp. These characterisations are conveniently summarised in the following table:

\section{Table 3: Characterisation of case studies}

\begin{tabular}{|c|c|c|c|c|}
\hline $\begin{array}{l}\text { Name of } \\
\text { Self-Help } \\
\text { Product }\end{array}$ & $\begin{array}{l}\text { Type of } \\
\text { Provider }\end{array}$ & $\begin{array}{l}\text { Personnel } \\
\text { involved in } \\
\text { development }\end{array}$ & $\begin{array}{l}\text { Provider } \\
\text { Motivation }\end{array}$ & $\begin{array}{l}\text { Nature of } \\
\text { self-help } \\
\text { environment }\end{array}$ \\
\hline $\begin{array}{l}\text { Probate } \\
\text { Kit }\end{array}$ & $\begin{array}{l}\text { Private } \\
\text { company }\end{array}$ & $\begin{array}{lr}\text { Non-legal } & \text { staff } \\
\text { with a } & \text { lawyer } \\
\text { checking } & \text { final } \\
\text { content }\end{array}$ & Profit driven & $\begin{array}{l}\text { Voluntary with users } \\
\text { choosing to do so in } \\
\text { order to save money }\end{array}$ \\
\hline $\begin{array}{l}\text { Residential } \\
\text { Tenancies } \\
\text { Guide }\end{array}$ & Government & $\begin{array}{lr}\text { Non-legal } & \text { staff } \\
\text { with } & \text { lawyers } \\
\text { checking } & \text { final } \\
\text { content } & \end{array}$ & $\begin{array}{lr}\text { Resource } & \text { driven } \\
\text { compliance } & \text { with } \\
\text { statutory obligations } \\
\text { (to } \\
\text { information, provide } \\
\text { education } \\
\begin{array}{l}\text { advisory and } \\
\text { associated with }\end{array} \\
\text { legislation) }\end{array}$ & $\begin{array}{l}\text { Obliged to engage in } \\
\text { self-help by the } \\
\text { requirements of the } \\
\text { legal process }\end{array}$ \\
\hline $\begin{array}{l}\text { Consumer } \\
\text { Guide }\end{array}$ & Legal Aid & $\begin{array}{l}\text { Primarily legally } \\
\text { qualified staff }\end{array}$ & $\begin{array}{l}\text { Resourcer driven } \\
\text { (pursuit of innovative } \\
\text { ways of giving legal } \\
\text { assistancer which } \\
\text { minimisereliance } \\
\text { upon individual } \\
\text { assistance) }\end{array}$ & $\begin{array}{l}\text { Obliged to engage in } \\
\text { self-help by the } \\
\text { requirements of the } \\
\text { legal process. }\end{array}$ \\
\hline $\begin{array}{l}\text { Child } \\
\text { Protection } \\
\text { Guide }\end{array}$ & $\begin{array}{l}\text { Community } \\
\text { legal centre }\end{array}$ & $\begin{array}{l}\text { Exclusively } \\
\text { legally qualified } \\
\text { staff }\end{array}$ & $\begin{array}{lr}\begin{array}{l}\text { Resource } \\
\text { (pursuit }\end{array} & \text { driven } \\
\text { community } & \text { of } \\
\text { education } & \text { activities } \\
\text { which } & \text { direct } \\
\text { resources to } & \text { widest } \\
\text { possible audience) }\end{array}$ & $\begin{array}{l}\text { Non-voluntary with } \\
\text { users required to } \\
\text { undertake self-help } \\
\text { due to lack of } \\
\text { financial resources } \\
\text { and ineligibility for } \\
\text { legal aid }\end{array}$ \\
\hline
\end{tabular}

\section{Common features of the case studies}

The case studies shared some obvious similarities. Each involved instances in which we sought to draw upon the experiences of people who engaged in legal work without engaging lawyers and often with some recourse to self-help resources which were in written form. With the exception of a DVD produced by the Tenants Union of Queensland ${ }^{46}$ [TUQ] in relation to tenancy disputes, we were unable to source alternative resources in non-written form in legal matters pertaining to each of the case studies. While the TUQ DVD was available at six

46 Tenants' Union of Queensland, "Small Claims Tribunal- Having you say" DVD (Brisbane: Tenants Union of Queensland, 2006). DVD is to assist tenants appearing in the Small Claims Tribunal for tenancy law matters. 
Brisbane public libraries ${ }^{47}$ (and could also be purchased directly from the TUQ), no specific data was available as to the number of people who had either viewed it or purchased a copy. Certainly none of the participants in the tenancy case study had accessed the DVD.

The written format of each of the self-help resources which formed the bases of our case studies suggests that each of the providers may have made similar assumptions about the likely literacy (and in some instances, numerical) skills of the intended audiences. While each of the resources attempts to present materials in a straightforward and plain English fashion, it is notable that by adopting a written form, the outcome is that only those self-helpers with reasonable levels of literacy could have recourse to any assistance the resources might provide. ${ }^{48}$ This point was not lost on each of the service providers who acknowledged that the resources they had produced did not address access barriers for people with limited literacy skills. While the providers of the resources relating to tenancies disputes, consumer problems and child protection matters indicated during our initial interviews with them that self-helpers with limited literacy levels might be able to access alternative services offered by them (for example, advice sessions, exceptional grants of legal aid or document preparation assistance), the Director of LKV, the producer of the Probate Kit indicated that it had made a deliberate decision to target people of reasonable literacy levels because "the process is so heavily oriented towards the completion of forms and paperwork, a person who is unable to read or write would just not be able to do it themselves"."

Our textual analysis of all four self-help resources indicated that each was targeted at self-helpers at a "point of legal exigency". By this, we mean that both the language and the content of the resources indicated that the intended audience was a person actually experiencing a current legal problem rather than a general reader who might, for example, be interested in the laws relating to child protection in Queensland or probates and wills in Victoria. This point is significant because it distinguishes those resources from more general community legal education resources which are designed to increase people's awareness of their legal rights and responsibilities or enlighten them about legal processes without actually contemplating the need for immediate reliance on that increased knowledge. ${ }^{50}$ Particularly in the context of resources developed by legal aid and

47 See Brisbane City Counsil, Brisbane City Council Library Catalogue, online: Brisbane City

Council Library Services 〈http://elibcat.library.brisbane.qld.gov.au >.

48 Research by Cumming \& Wilson has identified similar literacy and numeracy concerns in relation

to ADR processes. They state that: "The literacy and numeracy demands of ADR, while perceived as a community evolved simple process, are high for any participant". Joy Cumming \& JM

Wilson, Literacy, Numeracyand Alternative Dispute Resolution (Adelaide: National Centre for

Vocational Educational Research, 2005) at 40.

49 Sedgeman transcript, supra note 28.

50 The National Community Legal Education Committee, Guidelines for the Management of

Community Legal Education Practice (Sydney: National Association of Community Legal Centres August 1995) at 4 notes that

"CLE comprises legal information and legal education, both of which have a legitimate role in the delivery of CLE, but should not be confused. Legal information is important because many people are powerless in particular situations primarily through lack of knowledge - knowledge is power. This is CLE at its most basic level. Information without education, however, may not achieve the objectives of CLE. Legal education encourages a critical understanding of the law and the legal system and allows an 
community legal centre bodies, the distinction between more generalised community education activities and specific self-help resources is a crucial and often confused one. As we shall discuss later, the distinction impacts significantly upon the issue of service provider motivations and the potential for a misfit between those motivations and the needs of the self-helper.

\section{Distinguishing features of the case studies}

As previously noted the four case studies differ significantly in terms of the type of legal problem encountered by the self-helper - from the "almost administrative" process of obtaining a grant of probate in the Supreme Court of Victoria which at least one self-helper described as "no more difficult than registering your car" ${ }^{, 51}$ to the legally (rather than procedurally) complex process of establishing the existence of a contractual relationship in pursuing a consumer claim through the Small Claims Tribunal in Queensland. As one might expect then, the levels of complexity associated with the individual legal tasks involved also vary, from accurately completing a simple and pre-printed form to preparing evidentiary materials in the form of a largely unstructured affidavit in which the self-helper must use both legal knowledge and personal judgement to determine what materials should be included.

The complexity of the discrete tasks associated with each of the legal transactions also influences the need to transmit information to the self-helper about:

- $\quad$ matters which are purely about the process required - the steps the self-helper must undertake; and/or

- materials which cover the substantive law relevant to that process.

In analysing the case studies data, we have sought to distinguish between process oriented information which we refer to as "procedural information" the focus of which is on "knowing how" to do something (including knowing what to do and when to do it) and "propositional information" which seeks to explain the relevant substantive law, legal concepts and legal structures and therefore speaks to the "knowing why" to do something within the self-help process. By way of illustration, information which seeks to explain how to fill out a form would, in our characterisation, be a form of "procedural information" while information which explains that a particular tribunal has jurisdiction to hear a type of legal matter would be a form of propositional knowledge in that it increases a person's understanding of why their claim can be dealt with by that tribunal. Again, this distinction between procedural and propositional information is, as we shall discuss in our findings below, a significant consideration which impacts upon user assessments about the utility of the self-help resources.

\footnotetext{
assessment of its impact or usefulness. It is contended that education must be a mechanism for consciousness raising, not simply an unquestioning acceptance of the status quo".

See also Annie Nash, People.dot.community- A Resource for Effective Community

Activism (Geelong: Villamanta Legal Service Inc, 2001).

51 Case Study \#1, Transcript 15 (on file with authors).
} 
A further significant difference between each of the case studies relates to the very different natures of each of the self-help providers - the private, non-legal for-profit provider Legal Kits of Victoria, the regulatory agency, the Residential Tenancies Authority, the non-profit government legal provider in Legal Aid Queensland, and the non-profit community based legal provider in the South West Brisbane Community Legal Service. These differences have a direct bearing on the motivations of each provider in developing and distributing self-help materials as our later discussions will consider.

The four case studies also suggested significant differences in the motivations of self-helpers to undertake the legal work. In the case of those using the Probate Kit the decision to engage in legal self-help was an entirely voluntary one, usually motivated by a desire to save money but not necessitated by that end. At the other extreme, those seeking to rely upon either the Parents Kit or the Kinship Kit did so out of necessity in the absence of both personal funds to employ legal assistance and any other forms of comprehensive legal support. Both of the case studies involving the Small Claims Tribunal (relating to the Consumer Guide and Tenancy Guide) involved users required to engage in legal self-help in order to resolve their problems (even though some would have chosen to engage a solicitor had that option been available to them).

Finally, as the demographic analysis indicates there were significant differences between the population groups of each case study. Those within the probate case study tended, by and large, to possess significantly higher levels of formal education as well as higher income levels than respondents in each of the other case studies. Indeed, there was a significant degree of homogeneity amongst probate case study respondents. Eighteen of the 21 respondents reported that their current or past occupations involved the ability to complete paperwork and organise and manage information, skills which we have identified as being core to the process of making an application for probate in the Supreme Court. Thirteen respondents in that study made specific and unprompted positive reference to the way in which the Probate Kit drew upon their existing skill levels sufficient to allow them to work through the application process while 16 respondents commented favourably upon the accessibility of the resource in terms of the language used. All 21 respondents had had previous involvement with the legal system; most notably in relation to conveyancing transactions with 19 of those indicating that there past legal involvement had involved the employment of a solicitor to undertake the necessary legal work on their behalf. An analysis of the income and basic asset levels of each of the 21 respondents indicates that none would have been eligible for legal aid funding had that been available in probate matters.

By contrast, there was a degree of homogeneity amongst those participating in the child protection case study but at the lower end of the socio-economic scale. Of the 16 participants, only one had completed secondary schooling. Two identified as having only a basic literacy level (sufficient for example to complete a basic social security form with personal details). We observed that a further 10 participants struggled with literacy issues during the course of the semi-structured interviews. All study respondents were in receipt of social security benefits (with half in receipt of an unemployment benefit and the remainder receiving either a disability pension (4) or an aged person's pension (4)). While 12 had had previous dealings with the legal system these had been in relation to criminal and 
family law matters and in each of those instances the person was represented by a solicitor (generally funded through the legal aid system). Again, an analysis of the income and basic asset levels of the 16 participants indicates that all would have been eligible for legal aid funding if it was available in those types of legal matters in which the respondents were involved. All participants fell clearly within the traditional client base of the service provider, SWBCLS which, like other community legal centres tends to focus on the provision of services to the most financially and socially disadvantaged sections within society.

The respondents in the consumer disputes case study reflected a much more diverse population group. This was evident, not only across age ranges but also across analyses of income and education levels which, we suggest, reflects the potential breadth of people in the general population who experience, at some time in their lives, difficulties in relation to general consumer and contractual matters. While the Consumer Guide which formed the basis of this case study was developed by Legal Aid Queensland it is notable that less than half of the respondents were aware of its existence and less than one quarter of all respondents used it to assist them in working through their legal matter. This might suggest a general belief within the surveyed population that consumer matters are not traditionally handled by legal aid agencies. Indeed, several respondents were surprised to learn that there was in fact a self-help resource produced by Legal Aid Queensland in consumer matters and indicated that they had not inquired of Legal Aid because they thought that they did not fit the traditional legal aid demographic.

There was a similar diverse population who participated in our case study on tenancy matters. More than half of the respondents had completed mid to late level secondary schooling while slightly more than 55\% drew their primary source of income from paid employment. What is notable about the population group is that all participants fell within the 18 to 50 year age range. This was perhaps unsurprising given Australian Bureau of Statistics data at the time we conducted the case study, indicated the median age for renters throughout Australia was $37 .^{52}$

This demographic data is significant, particularly in relation to socio-economic indicators relevant to income and education levels in terms of the capabilities of self-helpers to undertake even basic steps associated with a legal process. Perhaps most interestingly, in terms of those case studies we explored is that the selfhelpers who expressed the greatest confidence in undertaking the particular legal process they were engaged in (notably those making application for probate) were easily the most educated and financially secure of all the self-helpers we interviewed. They were also engaged in what, at least in terms of legal knowledge and skills, could be considered to be the most straightforward of the different legal matters we have explored. By contrast, respondents within the child protection case study had the lowest levels of education and significantly lower levels of financial resources than any of the other population groups in the other case studies. They were also confronted with what, we suggest were the most

52 As the Australian Bureau of Statistics notes "(R)enters tend to be a younger group than owner-

occupier households. In 2005-06, the median age for renters (based on the age of the household reference person) was 37 years, which was 15 years younger than the median age for owneroccupier households (52 years). See Australian Bureau of Statistics, Australian Social Trends, online: Australian Bureau of Statistics <http://www.abs.gov.au/AUSSTATS/abs@.nsf/Lookup/4102.0Chapter9002008>. 
technically and legally complex matters of those we studied. It is perhaps unsurprising, as will be highlighted in the remainder of this article, that those in the child protection case study expressed the greatest inability and frustration in undertaking self-help in resolving their legal problems.

\section{B. Identification of some key findings}

This section focuses on three specific findings arising from the four case studies. These findings may be conveniently summarised as follows:

1. Self-helpers within the legal system are principally motivated by a desire to resolve their legal issues with minimal expenditure of resources including time, money and intellectual engagement. While they are, of course, emotionally invested in the outcome of their legal issue, they tend to measure the utility of legal self-help resources by whether those resources allow them to quickly, easily and directly enter and exit the legal system. Although a "desirable outcome" was also a factor it was not the sole determinant of self-helpers' measures of utility;

2. The providers of self-help legal resources tend to develop those resources by reference to their own motivations - to make profit, to alleviate pressure on other services, to meet statutory requirements or to fill what they perceive to be gaps in the legal system. Those motivations inform not only who develops a product and how it is developed but also influence the content of the resources developed. Because the motivations of providers differ widely from those of end-users, the self-helpers themselves, the resulting product may not be as useful to the user as might be hoped for or expected by the provider; and

3. The context and complexity of legal problems and processes significantly impacts upon the ability of self-helpers to quickly, easily and directly enter and exit the legal system. Where the nature of the legal process necessarily entails more than a basic level of intellectual engagement by the self-helper, for example where the self-helper must make personal decisions about available options, self-help resources may be less effective in instances where the selfhelper's intellectual engagement is limited to following well-defined processes with predictable outcomes.

\section{User motivations and measures of utility}

Users in each of the case studies were asked about their initial reasons for engaging in legal self-help and asked to nominate their primary reason for pursuing their legal matter through self-help mechanisms. These reasons varied across each case study but fell into a category of being either a purely voluntary personal choice or a forced choice in order to undertake the task. 
Table 4: Primary motivations for engaging in self-help

\begin{tabular}{|c|c|c|c|c|}
\hline $\begin{array}{l}\text { Reasons for } \\
\text { undertaking } \\
\text { self-help }\end{array}$ & $\begin{array}{l}\text { Case Study \#1 } \\
\text { Probate } \\
N=21\end{array}$ & $\begin{array}{l}\text { Case Study \# } 2 \\
\text { Tenancy } \\
N=26\end{array}$ & $\begin{array}{l}\text { Case Study \# } 3 \\
\text { Contractual } \\
\text { Dispute } \\
N=19\end{array}$ & $\begin{array}{l}\text { Case Study \# } 4 \\
\text { Child protection } \\
N=16\end{array}$ \\
\hline Personal choice & 19 & 1 & 7 & 0 \\
\hline Cost saving & 12 & 1 & 6 & 0 \\
\hline $\begin{array}{l}\text { Sense of } \\
\text { personal } \\
\text { capability }\end{array}$ & 7 & 0 & 1 & 0 \\
\hline $\begin{array}{l}\text { Involuntary } \\
\text { personal choice }\end{array}$ & 2 & 25 & 12 & 16 \\
\hline $\begin{array}{l}\text { Financial } \\
\text { inability to } \\
\text { afford } \\
\text { lawyer }\end{array}$ & 0 & 1 & 1 & 14 \\
\hline $\begin{array}{l}\text { Mistrust of } \\
\text { lawyers }\end{array}$ & 2 & 2 & 1 & 2 \\
\hline $\begin{array}{l}\text { Required by } \\
\text { forum or } \\
\text { system }\end{array}$ & 0 & 23 & 10 & 0 \\
\hline
\end{tabular}

Those who made a voluntary choice to engage in self-help generally did so because they either sought to save money or because they had a sense of personal capability in terms of being able to complete the required legal tasks and steps. This was particularly true in relation to the Probate case study in which all 26 respondents indicated that their decision to engage in self-help was an entirely voluntary one with many reporting that their reasons for doing so were to "save money" and "because I can", whereas those study participants whose legal problems arose within a system which mandated self-help (notably claims in the Small Claims Tribunal) more often than not reported that they "had no choice". Even in the Consumer Disputes case study, where seven respondents indicated that the choice to engage in self-help was a purely voluntary one, more than $60 \%$ of the remaining respondents indicated that it was a choice forced upon them by virtue of the compulsory self-help nature of the dispute resolution forum.

In the child protection system where self-help is neither mandated nor indeed encouraged by the system itself, all 16 participants felt that they had little or no choice, with $90 \%$ indicating that they were forced into a process of selfrepresentation because of their financial circumstances, a point reflected in the disadvantaged socio-economic backgrounds of those who participated in the child protection case study and exacerbated by legal aid policy in relation to funding of child protection matters.

By contrast, there was a significant degree of uniformity across all case studies in terms of the overall motivation or objective of self-helpers when engaging with the legal system. Respondents in each study were asked to put aside the substantive outcome they wished to achieve and reflect upon what they hoped or wished to achieve using legal self-help resources. While variously expressed, the overwhelming majority of participants in each case study talked of a need for and a desire to achieve a speedy (and, if possible, favourable) legal outcome while spending as little time, money and energy as possible on the process. 
"I didn't start the case. It was started by the landlord. I wanted ultimately for the case to go away! It was a great annoyance." and

"I just wanted to get my money back...I didn't really want to go to court but I really needed the money.,

and

"I want my kids back. I'm not here because I like being here. This isn't my idea of fun. I'm here because that's what I have to do to get what I want...I just want to get on with it and take my kids home.",

Even those in the Probate case study, all of whom had voluntarily chosen to pursue self-help in working through their legal matter focused on a desire to achieve a quick and cheap resolution. For example, seven participants specifically reflected on the way in which self-help obviated the time delays associated with instructing a lawyer as well as the speed of being able to deal with problems as they arose rather than waiting on communications from lawyers. Two others talked about the time and energy saved by being in control of the process and therefore being able to deal with steps in the process when time was available rather than in accordance with timeframes determined externally.

Our analysis of transcripts from each of the case studies indicated that selfhelpers were uninterested in engaging with the relevant legal processes at a level which increased their familiarity with the legal system above and beyond simply navigating through it. There is for example an absence of comment in any of the transcripts about the legal processes being "interesting" or "exciting". Rather, users saw self-help as a one-way ticket through a "necessary" legal process and, regardless of whether they had chosen to take the journey or felt forced by circumstance, or the system itself to do so, they did not anticipate returning to the system again. Nor did they see that the process of engagement provided them with transportable skills which might be useful in other legal and non-legal processes.

The observation that self-helpers want an immediate, cost effective and favourable legal outcome is hardly surprising. But we were also able to observe in all case studies a level of disengagement with the very legal processes that the participants were seeking to rely upon. This was evident in responses to two specific questions asked of all participants. Initially, participants were asked to recount any specific legal tasks they had undertaken while engaging with their legal matter. In each of the four studies less than half of the participants could recount more than two steps or specific tasks in the relevant process.

Participants were then provided with a generic list of relevant legal steps (not chronologically organised) associated with the particular type of legal process in which they had been engaged and were asked to identify:

- $\quad$ which steps they had actually undertaken; and

- in what order those steps had been undertaken.

53 Case Study \#3, Transcript 4 (on file with authors).

54 Case Study \#2, Transcript 2 (on file with authors).

55 Case Study \#4, Transcript 9 (on file with authors). 
Table 5: Respondent memory and ability to recall legal process

\begin{tabular}{|c|c|c|c|c|}
\hline & $\begin{array}{l}\text { Case Study } \\
\# 1 \\
\text { Probate } \\
N=21\end{array}$ & $\begin{array}{l}\text { Case Study \# } \\
2 \\
\text { Tenancy } \\
N=26\end{array}$ & $\begin{array}{l}\text { Case Study \# 3 } \\
\text { Contractual } \\
\text { Dispute } \\
N=19\end{array}$ & $\begin{array}{l}\text { Case Study \# } \\
4 \\
\text { Child } \\
\text { protection } \\
N=16\end{array}$ \\
\hline $\begin{array}{l}\text { Easily able to recall } \\
\text { from memory tasks } \\
\text { undertaken }\end{array}$ & 3 & 2 & 1 & 0 \\
\hline $\begin{array}{lr}\text { Expressed difficulty } \\
\text { in recalling } & \text { from } \\
\text { memory } & \text { tasks } \\
\text { undertaken } & \end{array}$ & 18 & 24 & 18 & 16 \\
\hline $\begin{array}{lr}\begin{array}{l}\text { Easily able } \\
\text { identify } \\
\text { undertaken tasks } \\
\text { presented with list }\end{array} \\
\end{array}$ & 9 & 6 & 8 & 1 \\
\hline 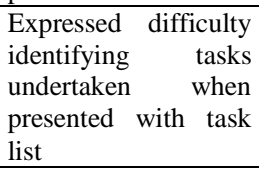 & 11 & 20 & 11 & 15 \\
\hline $\begin{array}{l}\text { Easily able to } \\
\text { identify } \\
\text { chronological order } \\
\text { of tasks undertaken } \\
\text { when presented with } \\
\text { task list }\end{array}$ & 7 & 3 & 4 & 0 \\
\hline $\begin{array}{l}\text { Expressed difficulty } \\
\text { identifying } \\
\text { chronological order } \\
\text { of tasks undertaken } \\
\text { when presented with } \\
\text { task list }\end{array}$ & 14 & 23 & 13 & 16 \\
\hline
\end{tabular}

The exercise highlighted significant levels of disengagement by self-helpers even when they have been immersed in particular legal work and suggests that their capacity or willingness to retain and recall information about the legal details of their experience is very limited. This is true even when they have engaged in selfhelp legal work voluntarily. Significant in our minds is that the levels of disengagement and inability to retain information about the legal process were high across all four case studies notwithstanding the differences in socio-economic backgrounds of the participants in each of the studies. As we shall suggest shortly, this raises serious concerns about the veracity of assumptions that laypeople can quickly and effectively be educated about aspects of the legal system and legal processes through their engagement with, and use of, self-help legal resources.

Our research findings indicate that those factors which motivated users to engage in self-help (the desire to achieve quick, cheap and simple access to the legal system and, if possible, a favourable outcome) were also the factors or considerations by which users assessed the utility of the self-help resources they used - that is they measured utility by how closely the resources matched their own motivations for undertaking self-help.

During interviews with self-helpers we asked them to reflect upon the self-help resources they had used throughout their legal matter and to identify what they 
found useful or less useful about those resources. We also asked them to explain how they formed that view. We did not provide prompts to participants in asking those questions preferring instead to listen to what the users themselves considered to have utility for them and why. Following transcription and analysis of each interview, responses to those questions (as well as responses to other questions) were then coded based upon an identification of whether respondents had positively or negatively commented on aspects of the self-help resource (as well as coding for no comments $[\mathrm{NC}]$ ).

Table 6: Analysis of utility factors identified by self-helpers

\begin{tabular}{|c|c|c|c|c|c|c|c|c|c|c|c|c|}
\hline & \multicolumn{3}{|c|}{$\begin{array}{l}\text { Case Study \#1 } \\
\text { Probate } \\
N=21\end{array}$} & \multicolumn{3}{|c|}{$\begin{array}{l}\text { Case Study \# } 2 \\
\text { Tenancy } \\
N=26\end{array}$} & \multicolumn{3}{|c|}{$\begin{array}{l}\text { Case Study \# } 3 \\
\text { Contractual } \\
\text { Dispute } \\
N=19 \\
\end{array}$} & \multicolumn{3}{|c|}{$\begin{array}{l}\text { Case Study \# } 4 \\
\text { Child } \\
\text { protection } \\
N=16\end{array}$} \\
\hline $\begin{array}{l}\text { Aware of primary } \\
\text { resource }\end{array}$ & \multicolumn{3}{|l|}{21} & \multicolumn{3}{|l|}{22} & \multicolumn{3}{|c|}{9} & \multicolumn{3}{|c|}{11} \\
\hline $\begin{array}{ll}\text { Utilised } & \text { primary } \\
\text { resource } & \\
\end{array}$ & \multicolumn{3}{|l|}{21} & \multicolumn{3}{|l|}{16} & \multicolumn{3}{|l|}{5} & \multicolumn{3}{|c|}{11} \\
\hline Primary resource & + & - & $N C$ & + & - & $N C$ & + & - & $N C$ & + & - & $N C$ \\
\hline $\begin{array}{l}\text { Easy to find and } \\
\text { obtain }\end{array}$ & 19 & 0 & 2 & 14 & 0 & 8 & 2 & 4 & 3 & 10 & 1 & 0 \\
\hline $\begin{array}{l}\text { Used language I } \\
\text { could understand }\end{array}$ & 16 & 1 & 4 & 9 & 2 & 5 & 1 & 3 & 1 & 4 & 4 & 3 \\
\hline $\begin{array}{lr}\text { Clearly identified } \\
\text { each of the } \\
\text { steps/tasks } \\
\text { needed I } \\
\text { undertake } & \text { to } \\
\end{array}$ & 12 & 0 & 9 & 9 & 3 & 4 & 1 & 4 & 0 & 0 & 4 & 7 \\
\hline $\begin{array}{l}\text { Had sufficient } \\
\text { detail to allow me } \\
\text { to complete each } \\
\text { of the steps/tasks } \\
\text { without further } \\
\text { assistance }\end{array}$ & 16 & 1 & 4 & 8 & 4 & 4 & 1 & 4 & 0 & 0 & 4 & 7 \\
\hline $\begin{array}{lr}\text { Gave accurate } \\
\text { indications } & \text { of } \\
\text { timeframes } & \text { for } \\
\text { each step/task } & \\
\end{array}$ & 11 & 0 & 10 & 5 & 3 & 8 & 0 & 3 & 2 & 0 & 2 & 9 \\
\hline $\begin{array}{l}\text { Followed a logical } \\
\text { order in outlining } \\
\text { steps and tasks }\end{array}$ & 14 & 0 & 8 & 8 & 2 & 6 & 0 & 4 & 1 & 0 & 5 & 6 \\
\hline $\begin{array}{l}\text { Was supplemented } \\
\text { by in-house } \\
\text { additional supports }\end{array}$ & 9 & 0 & 12 & 8 & 2 & 6 & 1 & 3 & 1 & 9 & 0 & 2 \\
\hline $\begin{array}{l}\text { Provided referrals } \\
\text { to other sources of } \\
\text { information } \\
\text { found useful }\end{array}$ & 0 & 0 & 21 & 7 & 0 & 9 & 0 & 4 & 1 & 0 & 0 & 11 \\
\hline $\begin{array}{l}\text { Worked for my } \\
\text { existing knowledge } \\
\text { base and skills }\end{array}$ & 13 & 0 & 8 & 4 & 1 & 11 & 1 & 3 & 1 & 2 & 5 & 4 \\
\hline $\begin{array}{l}\text { Worked within my } \\
\text { existing financial } \\
\text { resource base }\end{array}$ & 20 & 0 & 1 & 2 & 1 & 13 & 0 & 5 & 0 & 1 & 3 & 7 \\
\hline $\begin{array}{l}\text { Encouraged my } \\
\text { self-help capacity }\end{array}$ & 19 & 0 & 2 & 8 & 1 & 7 & 0 & 5 & 0 & 0 & 3 & 8 \\
\hline
\end{tabular}


Of the four self-help resources examined, those that drew the most favourable assessment from users were those that:

- related to legal processes which could be broken down into clearly identifiable steps and legal tasks which progressed in a linear fashion towards an outcome;

- related to legal matters in which it was possible to give reasonably accurate indicators to users of the time frame in which their legal matter could be expected to progress through each of the stages of the overall process;

- assumed a capacity on the part of the user to work through the legal work without needing to outlay additional financial resources in order to access further legal advice or services; and

- assumed either pre-existing knowledge of the relevant substantive law or did not require the user to have any knowledge of the substantive law in order to navigate the procedural requirements.

Users of the LKV Probate Kit expressed the highest levels of product satisfaction in comparison with users of the other three self-help resources we examined in the case studies. Indeed, Probate Kit users spoke in glowing terms about the product and consistently made reference to its "value for money", "straightforward" and "easy-to-follow" content and the Kit's focus on the practical "how to" of obtaining a grant of probate. Several users specifically identified the way in which the product provided the type of information a self-helper would need to know (for example, exactly how to get to the Supreme Court registry, and the location of nearby parking) without presuming prior knowledge that a lawyer would have. Others commented favourably upon the way in which the Kit encouraged in users a sense of their capacity to do it well, as well as a lawyer might do it.

Similarly, the users of the RTA Tenancy Guide expressed very positive views about the way in which the Guide provided step by step instructions which were focused on reaching an outcome. Users also commented favourably on the way in which the Guide was focused on the legal procedure rather than the relevant substantive law relating to tenancy matters, with several users specifically commenting that they already knew the relevant law in light of the mandatory information provided to tenants at the commencement of a tenancy agreement. In four instances the self-helper had had previous experience with the legal processes associated with tenancy matters. Those who used the Guide indicated that the way in which their matter progressed through the process was very much in accordance with the process outlined in the Guide and they therefore drew some comfort as their case progressed through each of the various stages.

In contrast, users of the self-help resources produced by LAQ and SWBCLS were critical of the way in which those resources tended to focus on matters they thought a lawyer might need to know but not what a non-legally trained self-helper might find useful. As one user of the Consumer Kit noted, the product did not provide information about the location of the Small Claims Tribunal because 
presumably "a lawyer would know that already but I don't". ${ }^{56}$ This was true not only in terms of practical information like the location of a court but also in terms of relevant substantive law. Users of both resources expressed frustration with the way in which they had to negotiate both substantive legal content and legal procedures and felt that the resources often privileged knowledge of the law over knowledge about the process itself. As one of the users of the Child Protection Parent's Kit observed when expressing frustration about the content of the Parent's Kit:

They took my kids. Does it matter if the law says they could or couldn't? They took them anyway. I need to know how to get them back. Tell me how to get my kids back, tell me I can get my kids back, tell me what to do, just don't keep telling me what the law says about what the Department can do. I've sort of got that figured out for myself already. ${ }^{57}$

In this regard many users, even those from quite disadvantaged socio-economic backgrounds, had an astute understanding of the differences between knowing what the law was and knowing how to work through the legal process. The reflections of users suggest a desire for a greater focus on useful "know-how" information rather than information which explains to them the relevant substantive law.

Users of both the LAQ and SWBCLS self-help resources commented upon what they saw as a repetitive message throughout the text of each document. This drew their attention to the "need to seek legal advice after every step" with respondents commenting about the way in which those messages made them feel that self-help was a less than preferable option in seeking resolution of their legal problem. As several also noted, the explicit references to the importance of getting a lawyer to advise them, check documents or confirm that their legal problems were being dealt with in the right jurisdiction, added to their sense of isolation within the system, particularly for those users who had limited or no recourse to ancillary legal support. Again, those responses are best typified by the statements from two self-helpers using the Consumer Guide:

"If I could have afforded a solicitor in the first place, I wouldn't need to use the booklet" ${ }^{, 58}$;

and

"Telling me to see a solicitor is a joke...just reminds me that I have a problem because I couldn't get legal advice" ${ }^{, 59}$.

It is notable that the legal processes associated with child protection matters in Queensland or consumer law matters through the then Small Claims Tribunal do not readily lend themselves to a linear and rigid representation of information in the same way that probate applications or tenancy disputes do. Child protection

\footnotetext{
Case Study \# 4, Transcript 3 (on file with authors).

Case Study \#4, Transcript 11 (on file with authors).

Case Study \#3, Transcript 16 (on file with authors).

Case Study \#3, Transcript 3 (on file with authors).
} 
matters, in particular, are often typified by unexpected turns with matters shuttling from negotiation to partial hearing to mediation and back again in ways which make it very difficult for the non-legally trained person to understand not only how much but even if the matter has actually progressed at all. A sense of bewilderment was expressed by several users of the Parent's Kit and the Kinship Kit who were unable to assess how far their legal matters had progressed because the conduct of their matters did not fit with what they understood of the process from the self-help resource. Similarly, those utilising the LAQ Consumer Guide expressed frustration that the process as it rolled out in the Small Claims Tribunal did not seem to follow the process outlined in the Guide. ${ }^{60}$

In summary, self-help users desire quick, cheap and straightforward mechanisms for the resolution of their own legal problems and they seek access to solutions which require minimum levels of engagement on their own part. While these factors motivate their engagement with the legal system, they are also used by self-helpers as measures of the utility of the particular self-help resources we explored. Those resources which most effectively provide quick, cheap and straightforward solutions scored much more highly in terms of user assessments than those which involved more complex legal problems and processes which potentially required greater personal engagement.

This observation is particularly relevant to the two other significant observations which we now explore - that provider motivations in developing selfhelp resources may be at odds with those of the end user, and that user assessments of utility suggest a great deal about the appropriateness or otherwise of self-help resources in complex legal situations.

\section{The significance of provider motives}

Our study revealed that there were real differences between the motivations of providers in developing the various self-help legal resources. Those motivations, we suggest, are important because they impact upon the provider's approach to the development, content and review of their self-help legal resources, which consequently affects users' experiences of the resources and ultimately users' assessments of their utility.

The most obvious difference observable across the case studies was between those providers who were motivated by a need to spread limited resources to provide some form of legal service to people who might otherwise not obtain legal assistance at all (Legal Aid Queensland and Southwest Brisbane Community Legal Service and, to a lesser extent, the Residential Tenancies Authority), and the provider which was driven by a desire to maximise its profit out of the development and sale of its resource to members of the public (Legal Kits of Victoria). As the Director of Legal Kits of Victoria noted "While we produce the kit to help people to seek probate, ultimately we are doing it to make money". ${ }^{61}$

There were also some important differences amongst the providers driven by resource imperatives. It is notable that the RTA's only area of focus was and is in relation to residential tenancies matters and, as such, it has the capacity,

60 Giddings, Hybrid Forums, supra note 2.

61 Sedgeman Transcript, supra note 28. 
knowledge base and mandate ${ }^{62}$ to focus on a discrete area of legal information and guidance with a known potential pool of self-helpers. By contrast, both LAQ and SWBCLS have responsibility for the provision of legal services across a broad spectrum - from family law to criminal law and civil matters. Both chose to develop specific self-help products to address areas in which either free or low cost legal services are generally not available, but where needy members of the public are recognised as seeking some level of service from.

Both LAQ and SWBCLS referred in interviews to their community legal education responsibilities and practices. They sought to characterise their self-help products as a part of their community legal education activities. ${ }^{63}$ This characterisation is of utmost importance because it underscores the key differences in the approach to the development and content of their products. Whereas both the products of LKV and the RTA tended, according to our textual analyses, to focus largely on procedural information with little or no detail about the relevant substantive law applicable to the type of legal dispute or transaction under consideration, the resources produced by the legal aid and community legal service providers contained significant blocks of text which sought to frame the dispute or transaction within the substantive law and the legal system more generally. By way of illustration, $46 \%$ of the text contained in the resource produced by LAQ to assist consumers in the Small Claims Tribunal was directed towards attempting to explain the jurisdiction of the Tribunal and outlining the substantive law relating to contracts (e.g. parties, elements and formation). In contrast, less than $8 \%$ of the text of the LKV Probate Kit was directed towards explanation of the substantive law and court jurisdiction.

The self-help resources produced by providers motivated by the imperative to spread limited resources to the widest possible audience, that is those produced by legal aid and community legal service agencies reflects the fact that legal service delivery is the core business of these organisations. This also helps to explain why the resources were developed by in-house legal staff who, as a result of the other services offered by the provider, noticed a "gap" or unmet legal need. The Parents Kit and the Kinship Kit developed by SWBCLS, for example, arose as a result of a lawyer employed by the service observing an increase in the number of clients presenting to the Service for assistance with child protection matters. ${ }^{64}$ This increase was prompted in part by findings by the Queensland Crime and Misconduct Commission inquiry into the abuse of children in foster care in 2004 which recommended, inter alia, that parents (and other kin) should be able to access legal advice and also have ongoing involvement in case planning in circumstances where children are removed from parental care and control. ${ }^{65}$ As

62 Residential Tenancies Act, QLD1994, s 289(e) contains specific reference to the RTA's function

to provide information, educational and advisory services about the operation of the Act.

63 Transcript of Interview with SWBCLS stakeholder and Transcript of Interview with LAQ

Director of Community Education, both on file with the authors.

64 Transcript of Interview with SWBCLS stakeholder, supra note 63. This increase was also observed by Legal Aid Queensland which reported "a steady increase in demand for legal aid in child protection matters" following the QCMC report (see Gwen Murray, Evaluation Report: Family group Meetings: Legal Aid Queensland Policy (Brisbane: Legal Aid Queensland, September 2007) at 7.

65 Crime and Misconduct Commission, Protecting children: an inquiry into abuse of children in foster care (Brisbane: Queensland Crime and Misconduct Commission, January 2004). 
staff of SWBCLS noted during interviews, the Parent and Kinship Kits were designed to provide at least some basic guidance to parents and kinship carers about the structure of the child protection system and the legal processes relevant to that system in an environment where neither Legal Aid Queensland nor government funding bodies were willing or able to increase direct legal service delivery levels Those staff acknowledged the limitations of the resources produced given the breadth of potential legal processes within the child protection system but indicated that the kits eased some of the pressure on staff solicitors in terms of providing basic information and guidance to those in need. Similarly, the Consumer Guide produced by LAQ was largely an attempt to ease pressure on advice services. This pressure was created by an influx of clients seeking on-going civil claims assistance, an area not traditionally prioritised for grants of legal aid in Queensland.

In the development of the LAQ Consumer Guide and the SWBCLS Parents and Kinship Kits, the initial decision to develop a self-help Guide was made internally by each provider and without reference to an external group of potential stakeholders. Moreover, neither provider utilised a formal process for ongoing review and development of the products. While each provider invited user feedback about content and utility (extended by way of a general invitation contained in the content of the resource) this process resulted in little or no feedback from users. ${ }^{66}$ Both providers also indicated during interviews that the decision to update or alter the content of the resource was undertaken by legal staff, usually annually, and as a result of changes to legislation or court and tribunal procedures. Given the absence of non-legal personnel involvement in the development and review of those kits, we would suggest that the resources produced by both SWBCLS and LAQ relevant to the two case studies represent the provider's perspective of what a layperson would need to navigate the legal system. That point is underscored further by the lack of involvement of potential users at the development stage of each resource and the very limited user feedback in the review stage.

By contrast, the genesis of the Probate Kit was LKV's decision to identify a key area of legal work in which people traditionally tended to engage a lawyer and where the individual tasks associated with the work could potentially be undertaken by reasonably competent self-helpers, given sufficient information and guidance. The identification of probate as such an area was made by non-lawyers, one of whom had past experience in undertaking self-help in proving a will in the Supreme Court, and the decision to develop a Probate Kit was only made after consultations with the Supreme Court Probate Office. Significantly, the kit was and continues to be updated at least twice annually, after obtaining user feedback through a comprehensive follow up process. This involves phone calls to every known user of the Kit in a given period, seeking their assessments of its utility. As the Director of LKV notes, this process ensures that the product is directed towards "giving the consumer exactly what they want"

66 As the Director of Community Education with LAQ noted during the course of our interview with her "We certainly invite and encourage users to provide feedback and we have, in the past, even mailed out pro forma feedback questionnaires to those we know have used one of our kits but the take-up rate is very, very low and perhaps reflects that they have moved on from the process" Transcript of Interview with LAQ Director of Community Education, supra note 63.

67 Sedgeman Transcript, supra note 28. 
As the body with statutory responsibility ${ }^{68}$ for the provision of information and guidance to tenants in Queensland, the decision by the RTA to develop the Tenancy Guide was effectively pre-determined by the enabling legislation. The Kit supplemented other RTA publications about tenancy matters and was developed with input from Small Claims Tribunal registry staff, in much the same way that the LKV Probate Kit drew upon input from Supreme Court registry staff. Tribunal staff were also involved in the ongoing development of the RTA resource as were users, albeit indirectly. The RTA relied heavily upon feedback from users who contacted the agency seeking additional information to supplement the information already in the Kit. Where appropriate, the RTA then sought to address those needs by incorporating additional material in the next available edition of the Kit.

In summary, both the RTA and LKV sought at least initially to include the insights of other stakeholders (Tribunal and court staff) in the development of their self-help products whereas LAQ and SWBCLS emphasised the insights of inhouse legal staff in terms of what might be required to address existing gaps in their own legal services. For the latter two agencies, those insights remained the key source of ideas and information in the subsequent review and updating of their resources, whereas both the RTA and LKV drew much more extensively on the insights of the end-users themselves.

It is notable that the two self-help products which drew the most favourable comments from study participants in terms of their utility (the Probate Kit and the Tenancy Guide) were those in which the perspectives of external stakeholders were initially sought and in which feedback from users was widely relied upon in ongoing review, development and improvement. In contrast, study participants who used the self-help resources produced by LAQ and SWBCLS tended to regard these as less helpful to them as they worked through the legal process. This invites the conclusion that the latter resources suffered to some extent from the absence of user input and feedback in their creation and ongoing development.

The resources developed by the more traditional providers of self-help, namely legal aid services and community legal centres, sought to convey both propositional knowledge (by way of information about the substantive law) and procedural knowledge (by way of information about the process-oriented steps) but often did not distinguish between the two. When interviewed, both these providers emphasised their goals included equipping citizens with both propositional knowledge and the procedural information they needed to navigate their way through each legal transaction. Their objective was to ensure that users not only knew "what" to do, but "why". This objective reflects a wider belief within the legal aid and community legal services sectors in Australia about the need to take opportunities to engage in community legal education, as a means to "empower" citizens through increased public awareness about law and legal processes generally. (We have discussed this matter more fully elsewhere. ${ }^{69}$ )

By contrast, the resources developed by Legal Kits of Victoria and the Residential Tenancies Authority tended to focus primarily upon procedural matters relevant to the particular legal transaction at hand. In part, this was because both were able to make some justifiable assumptions about the level of legal knowledge 
and understanding that a self-helper may have in relation to the subject matter of their respective products. The Director of LKV's view that "if a person has decided to do it themselves, we can safely assume that they know enough about probate and what it is, to do away with long winded explanations", ${ }^{70}$ was borne out by other interview data from the case study and particularly the high number of participants who indicated that the resource contained useful information at a level they could readily understand While most users could not articulate how or when they knew that there was a need to apply for probate of a will, all of them indicated that they knew that there was such a process before they obtained a copy of the Probate Kit. Similarly, the RTA was able to rely upon the mandatory provision of the Know Your Rights Guide to all tenants at the beginning of each tenancy agreement. This provides self-helpers with sufficient understanding of their legal rights and responsibilities and means that the RTA does not need to include lengthy explanations of these in the SCT Tenancy Guide. The RTA was also able to make a reasonable assumption that many people have some familiarity with the rights and obligations arising under tenancy arrangements. This was evident in persistent statements in the interviews that the participants "knew their rights" or had "prior experience" with tenancy matters.

By way of summary on this point, the majority of users who relied upon selfhelp resources produced by legal aid and community legal centre agencies expressed frustration with the high levels of background substantive legal information contained in those resources. In contrast respondents using the resources produced by the private service provider and the statutory agency tended to reflect positively upon the way in which the resource focused almost entirely on the process of making a claim or application rather than the substantive law.

Finally, in regard to overall provider motives, there may also be some significance in the observation that the products of the traditional suppliers of selfhelp legal resources were developed almost exclusively by trained lawyers who relied heavily on the observations of legal personnel. The resulting resources might therefore have tended to privilege the kind of information that lawyers felt they personally would need to know, rather than the kind of information that untrained legal self-helpers felt they should know. The most obvious example of this was provided by a user of the LAQ Consumer Guide, noting that while the Guide provided detailed information about how to identify whether a party was a "consumer" within the meaning of the Small Claims Tribunal, it omitted to inform users where the Tribunal was actually located. Notably, both the LKV and RTA products were developed by non-lawyers and, while lawyers proofed the resources prior to publication, their input was designed only to ensure the accuracy of the legal content.

\section{THE IMPACT OF CONTEXT AND COMPLEXITY}

\section{A. Context}

We referred earlier to the influence of context on the effectiveness of self-help legal resources. We define context to include the following considerations relevant to the environment in which legal self-helpers may find themselves:

70 Sedgeman Transcript, supra note 228. 
- Whether the legal system tolerates or mandates legal selfhelp, particularly in terms of the attitudes of those responsible for the administration of that system (including court personnel, judges and lawyers who may be advising the self-helper or representing the other party);

- Whether the legal environment is primarily concerned with administrative processes or is a litigious one, including where forms of alternative dispute resolution impact on the experiences of the self-helper;

- Whether the context is potentially an emotional one for the self-helper. Any legal matter may potentially be stressful, especially for those who are not legally qualified and any self-helper may be emotionally invested in the outcome of their problem. Our concern has been to identify those environments in which personal and emotional attachment to the outcome may impair or compromise a self-helper's ability to make logical and rational choices, or weigh options in a reasonably informed manner; and

- Whether the legal landscape and the self-help process afford the self-helper access to ancillary legal support (offered either by the product provider or by other providers).

Significantly, the four case studies indicate a variety of self-help contexts, from those which mandate self-help work (notably Small Claims Tribunal matters) to those which are somewhat benign in the "tolerance" of self-helpers within the system (Supreme Court probate matters) and then to those which are quite hostile and unforgiving of self-helpers (child protection matters). This aspect of context did not by itself have a significant bearing on user assessments of the utility of self-help resources. At one extreme, users within the child protection system had great difficulty navigating the terrain given the sometimes openly hostile attitudes of stakeholders, including Tribunal personnel and Child Protection Departmental officers. Yet users within systems which mandated self-help also experienced frustration in working through the processes. For example, more than $60 \%$ of participants in the Consumer Division of the Small Claims Tribunal expressed concern that the adjudicators in particular matters seemed not to honour processes designed for self-helpers and instead tended to operate their tribunals as if they were courts, and as if the self-helpers were (or should be) lawyers.

Whether the legal process was adversarial or not had some impact upon user perceptions of their self-help journey as well as the utility of self-help resources designed to assist them. Users who tended to be critical of the resources produced by LAQ and SWBCLS were invariably involved in highly litigious legal matters and some of their frustrations with these resources, we suggest, reflect the inability of litigious processes to proceed routinely along a neat and predictable path. Indeed, we suggest that it would be extremely difficult for self-help resource developers to provide entirely accessible and useful materials for use in litigious environments. This stems from the virtual impossibility of anticipating and

71 Giddings, Hybrid Forums, supra note 2. 
addressing the many and varied contingencies which might arise in the process of working through highly litigious disputes.

By contrast, the more positive experiences of self-helpers who utilised the Probate Kit shows that self-help legal resources have the potential to be very effective, even in court-based proceedings, where the processes can be mapped out for self-helpers in a linear fashion with reasonably ascertainable timeframes for each step. The probate process lends itself well to regularity and progression because it is possible to anticipate the few instances where a problem might arise, which require a deviation from the standard process. Another feature of the probate process is that the timeframes can be mapped in a way which allows the user to recognise what stage they have reached at any given time.

To some extent this was true also of the litigious environment associated with tenancy matters covered by the Residential Tenancies Guide. While that process, unlike the single party process associated with an uncontested probate application, might lead to multiple party involvement, it is possible for the self-help resource providers to predict with some degree of accuracy the various points at which the process might deviate from the norm and to provide guidance to the self-helper accordingly.

Each of the four case studies contained respondents who were emotionally involved in their legal matters. However, some experienced deep and sustained emotional turbulence throughout the self-help journey while others experienced moments of emotional stress. This was particularly evident in the comparison between probate applicants and those involved in child protection proceedings. In the majority of instances, Probate Kit users reported that at particular points in the process they reflected on the grief of losing a loved one (most notably when completing the inventory of assets and in completing documents which required them to access the deceased's death certificate) but indicated that they otherwise felt that their grief did not intrude on the legal work they were undertaking. As one participant noted "There were a few tears when I was filling out the inventory of mum's assets, just because it reminded me so much of her. I'd just put it [the inventory] aside and come back to it when I felt stronger or less emotional". In comparison, all of the 16 respondents those who were involved in child protection matters, whether it was a process for the return of their child or a dispute about access to the child in the care of the state, indicated that every stage of the process was traumatic and emotionally charged. Each reported that their despair, anger or bewilderment intruded on their ability to comprehend what was then occurring or to make sufficient or even any progress. As one participant noted:

I'm sitting in the Tribunal and they're telling me I can see my kids once a month and would I agree to supervision and where would I like the supervision at and I'm like "You haven't even heard from me about how [children's names] should be at home", and so they put the case off again and told me again that I should get help, lawyers and stuff. They said I was uncooperative but if I'd [have] known it would be another six weeks before we could come back to court I'd [have] agreed to just about anything just to see (children's name). I just didn't know what was going on",

Self-helpers in tenancy matters and consumer disputes were impacted less by emotional factors. With only three exceptions, those who had worked through a

72 Case Study \#4, Transcript 5 (on file with authors). 
tenancy dispute tended to be blasé about the outcome because in the vast majority of instances they had already secured alternative accommodation or had reconciled themselves to what they saw would be the inevitable outcome. The three users who became emotionally involved in the process tended to do so because they felt compelled to pursue the matter through the legal system as a "matter of justice", believing that they had been poorly treated by the other party, or out of a desire to prevent someone else from experiencing similar treatment. These sentiments were shared by more than half of the respondent users of LAQ's Consumer Guide with most of those respondents commenting about "the principle of the case".

\section{B. Complexity}

Our initial findings, perhaps unsurprisingly, suggest that context is also impacted by the complexity of particular legal tasks in the self-help process. It perhaps states the obvious to suggest that the more complex a legal transaction is, the more likely it is that a non-legally trained person may struggle to manage it. But this may assume the superiority of so-called legal "skills" and legal knowledge over other skills which a user may or may not have.

To avoid privileging legal skills over the other skills that a self-helper can utilise in addressing a task, we sought to develop a matrix of knowledge and skills associated with the different legal tasks undertaken by self-helpers in the four case studies. That matrix reflects both legal and non-legal skills and knowledge. The table below maps, within each case study, the types of legal and non-legal skills which would reasonably be required of each self-helper who made use each of the four resources we explored. In each case, the relationship between those skills and the context and nature of the legal transaction itself is also indicated.

\begin{tabular}{|c|c|c|c|c|}
\hline Case Study & $\begin{array}{l}\text { Legal Knowledge } \\
\text { and Skills }\end{array}$ & $\begin{array}{l}\text { Non-Legal } \\
\text { Knowledge and } \\
\text { skills }\end{array}$ & $\begin{array}{l}\text { Overall nature } \\
\text { of legal } \\
\text { transaction }\end{array}$ & Context \\
\hline Probate Kit & $\begin{array}{l}\text { Basic understanding } \\
\text { of nature and } \\
\text { purpose of applying } \\
\text { for probate. } \\
\text { No other legal } \\
\text { skills/knowledge } \\
\text { required. }\end{array}$ & $\begin{array}{l}\text { Literacy and } \\
\text { numeracy skills } \\
\text { sufficient to read } \\
\text { and complete } \\
\text { pre-printed } \\
\text { forms. } \\
\text { Limited skills in } \\
\text { making informed } \\
\text { personal } \\
\text { decisions. }\end{array}$ & $\begin{array}{l}\text { Largely } \\
\text { administrative } \\
\text { and non-legal in } \\
\text { nature. } \\
\text { Can re-apply if } \\
\text { initially } \\
\text { unsuccessful. }\end{array}$ & $\begin{array}{l}\text { Benign system } \\
\text { which tolerates } \\
\text { self-helpers. } \\
\text { Adjudicator has } \\
\text { very limited } \\
\text { discretionary } \\
\text { powers. } \\
\text { Reasonable } \\
\text { levels of } \\
\text { emotional } \\
\text { attachment and } \\
\text { detachment in } \\
\text { the process. }\end{array}$ \\
\hline $\begin{array}{l}\text { Tenancy } \\
\text { Guide }\end{array}$ & $\begin{array}{l}\text { Basic understanding } \\
\text { of tenancy law. } \\
\text { Ability to determine } \\
\text { relevancy and } \\
\text { admissibility of } \\
\text { evidence. }\end{array}$ & $\begin{array}{l}\text { Literacy skills } \\
\text { sufficient to read } \\
\text { and complete } \\
\text { pre-printed } \\
\text { forms. } \\
\text { Reasonable } \\
\text { decision making } \\
\text { skills necessary } \\
\text { to consider } \\
\text { proposals for } \\
\text { settlement and } \\
\text { available }\end{array}$ & $\begin{array}{l}\text { Both } \\
\text { administrative } \\
\text { and legal in } \\
\text { nature although } \\
\text { level of legal } \\
\text { competency is } \\
\text { moderated by } \\
\text { forum as one } \\
\text { mandating self- } \\
\text { help. }\end{array}$ & $\begin{array}{l}\text { Mandated self- } \\
\text { help system. } \\
\text { Adjudicator has } \\
\text { some } \\
\text { discretionary } \\
\text { powers. } \\
\text { There is a more } \\
\text { comprehensive } \\
\text { statutory } \\
\text { framework with } \\
\text { a stronger focus } \\
\text { on protecting }\end{array}$ \\
\hline
\end{tabular}




\begin{tabular}{|c|c|c|c|c|}
\hline & & $\begin{array}{l}\text { alternative } \\
\text { options. }\end{array}$ & & $\begin{array}{l}\text { tenants. } \\
\text { Reasonable } \\
\text { levels of } \\
\text { emotional } \\
\text { attachment and } \\
\text { detachment in } \\
\text { the process. }\end{array}$ \\
\hline $\begin{array}{l}\text { Consumer } \\
\text { Guide }\end{array}$ & $\begin{array}{l}\text { Legal knowledge } \\
\text { sufficient to self- } \\
\text { assess whether Act } \\
\text { and jurisdiction } \\
\text { applies. } \\
\text { Ability to determine } \\
\text { relevancy and } \\
\text { admissibility of } \\
\text { evidence. } \\
\text { Ability to prepare } \\
\text { basic affidavit } \\
\text { material. }\end{array}$ & $\begin{array}{l}\text { Literacy and } \\
\text { numeracy skills } \\
\text { sufficient to read } \\
\text { and complete } \\
\text { pre-printed } \\
\text { forms. } \\
\text { Capacity to } \\
\text { verbally present } \\
\text { relevant } \\
\text { information in } \\
\text { coherent manner. } \\
\text { Solid personal } \\
\text { decision making } \\
\text { skills necessary } \\
\text { to consider } \\
\text { proposals for } \\
\text { settlement and } \\
\text { available } \\
\text { alternative } \\
\text { options. }\end{array}$ & $\begin{array}{l}\text { Both } \\
\text { administrative } \\
\text { and legal in } \\
\text { nature with } \\
\text { expectation of } \\
\text { solid legal } \\
\text { knowledge of } \\
\text { basic consumer } \\
\text { laws. }\end{array}$ & $\begin{array}{l}\text { Mandated self- } \\
\text { help system. } \\
\text { Adjudicator has } \\
\text { wide-ranging } \\
\text { discretionary } \\
\text { powers. } \\
\text { Reasonable } \\
\text { levels of } \\
\text { emotional } \\
\text { attachment and } \\
\text { detachment in } \\
\text { the process. }\end{array}$ \\
\hline $\begin{array}{l}\text { Child } \\
\text { Protection } \\
\text { Kits }\end{array}$ & $\begin{array}{l}\text { Detailed knowledge } \\
\text { of relevant and } \\
\text { multiple laws } \\
\text { relevant to } \\
\text { proceedings. } \\
\text { Ability to determine } \\
\text { relevancy and } \\
\text { admissibility of } \\
\text { evidence. } \\
\text { Ability to prepare } \\
\text { detailed affidavit } \\
\text { materials (for } \\
\text { tribunal processes } \\
\text { only). }\end{array}$ & $\begin{array}{l}\text { Solid literacy } \\
\text { skills sufficient } \\
\text { to read and } \\
\text { complete pre- } \\
\text { printed forms } \\
\text { and structure and } \\
\text { present relevant } \\
\text { information in } \\
\text { coherent manner. } \\
\text { High level } \\
\text { personal decision } \\
\text { making skills } \\
\text { necessary to } \\
\text { consider } \\
\text { proposals for } \\
\text { settlement and } \\
\text { available } \\
\text { alternative } \\
\text { options }\end{array}$ & $\begin{array}{l}\text { Largely legal in } \\
\text { nature with high } \\
\text { levels of } \\
\text { complexity in } \\
\text { terms of } \\
\text { intersections of } \\
\text { child protection } \\
\text { laws and other } \\
\text { laws (criminal } \\
\text { and family law } \\
\text { being the most } \\
\text { notable). }\end{array}$ & $\begin{array}{l}\text { Hostile system } \\
\text { for self-helpers, } \\
\text { framed with legal } \\
\text { representatives in } \\
\text { mind. } \\
\text { Adjudicator had } \\
\text { wide-ranging } \\
\text { discretionary } \\
\text { powers. } \\
\text { Highly } \\
\text { emotionally } \\
\text { charged } \\
\text { environment } \\
\text { involving users } \\
\text { who experience } \\
\text { high levels of } \\
\text { emotional } \\
\text { attachment in the } \\
\text { process and to } \\
\text { the outcome. }\end{array}$ \\
\hline
\end{tabular}

What is significant about this analysis is that the transactions that are most legally complex (notably those associated with child protection matters but to a lesser extent consumer matters in the Small Claims Tribunal) are also ones that require more advanced non-legal skills, such as the ability to make personal decisions associated with the potential outcomes of the legal process. Perhaps unsurprisingly, the Guides and self-help kits within these fields scored much lower on users' measures of utility than those associated with the much less complex 
(both legally and non-legally) transactions. Users tended to regard more positively those resources which involved:

- largely administrative types of legal tasks;

- legal processes which required relatively limited personal skills on the part of the user;

- transactions in which the ultimate decision maker had limited or no discretionary powers; and

- circumstances in which the user, while personally invested in the outcome, was not overawed by the emotional proximity of the subject matter of the legal issue.

It comes as little surprise that the case study in which users expressed lower levels of satisfaction with the available self-help resource involved child protection proceedings requiring comprehensive personal skills and detailed legal skills and knowledge and also accorded the decision maker wide discretionary powers.

\section{CONCLUSION}

Our research findings indicate that the self-help legal resources we have studied can usefully assist those who either choose, or are obliged, to engage in the resolution of their own legal problems. However, the utility of these resources is heavily dependent upon a clear and close alignment between the goals and motivations of the providers and the immediate practical needs of the users. Equipping legal self-helpers with relevant information, guidance and know-how, so that they become effective self-helpers, is often, but not always, possible. Much depends upon the nature of the legal work at hand, the context in which it is attempted, and the abilities of the individuals involved. As to the latter, our findings suggest that printed, legal self-help materials in kit and Guide form are likely to have the greatest utility when users are already equipped with relevant skills (such as basic literacy skills sufficient to allow them to complete pre-printed forms) and also have at least a basic knowledge of the relevant legal domain.

As to the matter of what we call "context", one of the central lessons to emerge from our case studies is that when providers are motivated to develop and offer their resources in order to create "informed citizens", rather than "effective legal self-helpers", there is a risk that the product may hinder rather than aid those in need. On the other hand, when self-help resources focus almost exclusively on what we have referred to as the procedural steps associated with the legal transaction, users are likely to make use of their prior yet limited legal knowledge, together with their existing skills, to achieve worthwhile and helpful legal outcomes.

These findings have implications for the development of legal self-help materials in the future. We suggest that it behooves all providers to evaluate carefully the reasons why, and the methods by which, they engage in the development and delivery of these resources. This is particularly important for traditional providers of legal services for the wider community, who with the best intentions may unwittingly construct unnecessary barriers to effective legal selfhelp. This is likely to be the result when resources focus unduly on achieving the providers' own goals of citizen empowerment and transformation rather than on 
the self-helper's more immediate goals of effective access to law and the timely resolution of individual legal challenges. In the design of self-help resources, the focus should be on the user and on the legal tasks at hand rather than on the wider reaches of the law and what it means for citizens in general.

Obtaining insights and feedback from users and potential users in a systematic manner is likely to enhance the utility of self-help legal resources. A way forward for would-be resource providers is to delineate their wider commitments to broad community legal education from their more targeted commitments to providing legal resources to people at points of legal need or even crisis. Both commitments are laudable and valuable to the community, but our findings suggest that their underlying purposes, targets and methods are often not synonymous.

\section{APPENDIX A - Self-Helper Interview Schedule}

\section{SUMMARY OF SEMI-STRUCTURED INTERVIEW SCHEDULE}

The schedule provided a structure only for the conduct of interviews. The number of questions asked/prompts provided was dependent upon the depth of answers from respondents. Additional questions were often asked based upon the respondent's initial answers in order to probe relevant issues and observations.

\section{Core}

- Are you involved in a case (describe category and jurisdiction - eg. tenancy matter in the Small Claims Tribunal).

- If no, have you been involved in a case (describe category and jurisdiction) within the last six months?

- Thinking about that case were/are you the person making the claim/applying to the court or the person defending the claim/responding to someone else's application?

- Is the case ongoing or has it been settled?

- What stage is the case currently at? (provide list of stages)

- Broadly what was that current/recent case about?

\section{Prior legal experience}

- Prior to the current/recent case have you ever been involved in other court or tribunal cases? Details including role/involvement of legal personnel?

- Have you had any formal legal education or training? (examples may include "legal studies at high school). Details?

- Have you ever worked in a job that requires you to have some understanding of the legal system? (examples might include legal secretary). Details?

- Apart from current/recent case, have you had other legal problems or matters where you have obtained legal advice? Details? 


\section{Current /recent self-help experience}

- In the current/recent case, did you engage in self-help? (Explain notion of "self-help")?

- What factors contributed to your decision to engage in selfhelp?

- What was the outcome you hoped to achieve in relation to the current/recent case?

- Aside from wishing to obtain a positive outcome, what other factors were important to you in deciding to pursue/defend the claim/application (Prompts if necessary time, control, money, convenience, emotional involvement, principle of the matter).

\section{Use of self-help resources}

- In this case did you use a copy of the (primary resource)

- In addition to (primary resource) did you obtain any other forms of legal support and assistance? (Prompts: saw a layer, used a different kit, guidance from friends, court). Details?

- Thinking about the (primary resource) and any other forms of assistance you used, how much of the information/knowledge you used in the case came from the primary resource?

\footnotetext{
All of my knowledge/information was from the primary resource Most of my knowledge/information

About half of my knowledge/information was from the primary resource

Only some of my knowledge/information

None of my knowledge/information
}

- If you did not use a copy of the (primary resource) did you obtain any other forms of legal support and assistance in your case? (Prompts: saw a lawyer, used a different kit, guidance from court, friends). Details?

- Is there any other legal support or information you would have liked in your case which was not available to you? What would that be? Why would that be helpful?

\section{About the primary resource}

- How did you know about the (primary resource)?

- How did the primary resource assist you in your legal matter? How did you use that resource?

- Was there information you needed about running your case which was not covered in the resource? How did you go about finding that information? 
- Were there particular legal tasks in your case that you found were easy? What were those tasks? What did you find easy about them?

- Thinking about those easier legal tasks, how helpful was the primary resource in helping you to work through the tasks?

- Were there particular legal tasks in your case that you found were difficult? What were those tasks? What did you find difficult about them?

- Thinking about those difficult legal tasks, how helpful was the primary resource in helping you to work through the tasks? Did you need to go outside the primary resource for further assistance?

- To what extent do you agree with the following statements?

$\begin{array}{ll}\text { Strongly Agree } & \text { SA } \\ \text { Somewhat Agree } & \text { SWA } \\ \text { Undecided } & \text { U } \\ \text { Somewhat Disagree } & \text { SWD } \\ \text { Strongly Disagree } & \text { SD }\end{array}$

I found the Guide easy to read and understand. Why?

I felt better prepared in conducting my case because I used the Guide. Why?

Ifelt more in control of my case because I used the Guide. Why?

The Guide helped me to achieve the outcome I wanted. Why?

The Guide provided enough information about how to do specific legal tasks.

Why?

- Do you have suggestions on how the primary resource might be improved?

\section{About other resources}

- If you used other resources what were they? How do you come to know about them?

- What was useful about those other resources? If you had not had access to them, what do you imagine might have been the impact on your case? On how you felt about your case or the steps you had to undertake?

\section{Retained knowledge of self-help and legal process}

- Thinking about current/recent case, what were the specific legal tasks you undertook in the process?

- In relation to each of those tasks, how did you know what to do? Sources of information and assistance?

- Looking now at this list of tasks common to these sorts of legal matters, please identify those tasks you undertook in your case?

- In relation to each of those tasks, how did you know what to do? Sources of information and assistance? 
- Looking at the list again, can you put in order those tasks that you undertook from the first one to the last one?

- How important were the following for you in pursuing your legal matter (1-10 with 1 being not at all important and 10 being essential)?

Knowing what to do at each step

Knowing how to undertake each step

Knowing why the step was important

Knowing in advance what the next step was

Knowing the timeframe for each step

\section{Skills and knowledge generally?}

- Apart from legal knowledge, when you think about the tasks you undertook in your legal matter what other skills did you use?

- Were there non-legal skills you think you needed but did not have? What do you do to address those skills?

- Thinking about what you learned about the legal process and the skills you used, can you think of any ways you might use that knowledge and skills in the future? In other legal matters? In non-legal matters?

\section{Commitment to self-help}

- If you had been able to use a lawyer to handle your case, would you have chosen to do that? Why/why not?

- Would your answer be the same if you knew in advance that you would obtain the same/different result? Why/why not?

- That's the end of the interview. Do you have any questions or anything else you want to say about your legal matter and the resources you used?

\section{APPENDIX B - Demographic Analysis}

Table C1: Age of respondents by case study (number of respondents in each case study)

\begin{tabular}{|l|l|l|l|l|l|l|l|}
\hline Age Brackets & $<\mathbf{1 8}$ & $\mathbf{1 8 - 2 5}$ & $\begin{array}{l}\mathbf{2 6 -} \\
\mathbf{3 5}\end{array}$ & $\mathbf{3 6 - 5 0}$ & $\mathbf{5 1 - 6 5}$ & $\mathbf{7 6 5}$ & Total \\
\hline $\begin{array}{l}\text { Case Study \# 1 } \\
\text { Probate }\end{array}$ & 0 & 0 & 3 & 14 & 4 & 0 & 21 \\
\hline $\begin{array}{l}\text { Case Study \# 2 } \\
\text { Tenancy }\end{array}$ & 0 & 8 & 12 & 6 & 0 & 0 & 26 \\
\hline $\begin{array}{l}\text { Case Study \# 3 } \\
\text { Consumer }\end{array}$ & 0 & 4 & 5 & 7 & 2 & 1 & 19 \\
\hline $\begin{array}{l}\text { Case Study \# 4 } \\
\text { Child protection }\end{array}$ & 0 & 5 & 3 & 5 & 3 & 0 & 16 \\
\hline
\end{tabular}


Table C2: Educational levels of respondents by case study (\% of respondents in each case study)

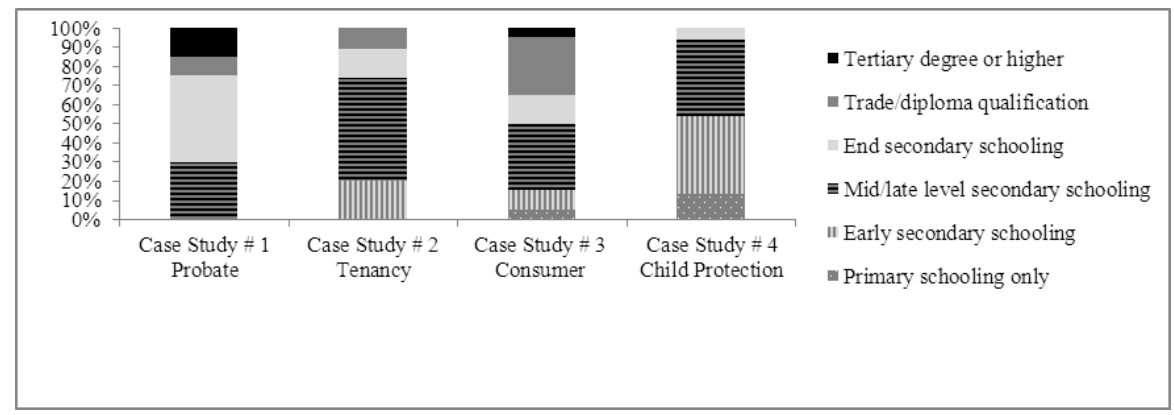

Table C3: Annual income levels by case study (\% of respondents in each case study)

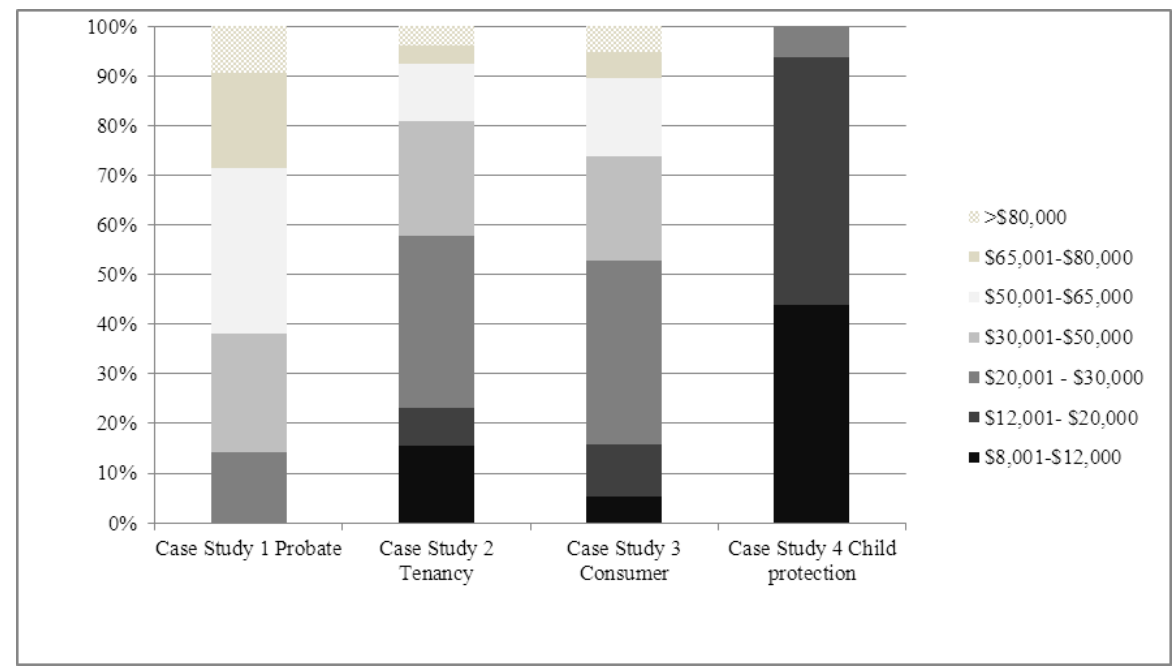

Notes: Australian median income for 2007-2008 was \$26,915 while single person unemployment benefit (Newstart allowance - adult level) was $\$ 11,682$. 
